\title{
Bioprospecting for Bioactive Peptide Production by Lactic Acid Bacteria Isolated from Fermented Dairy Food
}

\author{
Davide Tagliazucchi ${ }^{\circledR}$, Serena Martini and Lisa Solieri * \\ Department of Life Sciences, University of Modena and Reggio Emilia, Via Amendola 2, 42122 Reggio Emilia, \\ Italy; davide.tagliazucchi@unimore.it (D.T.); serena.martini@unimore.it (S.M.) \\ * Correspondence: lisa.solieri@unimore.it; Tel.: +39-0522-2026
}

Received: 18 October 2019; Accepted: 1 November 2019; Published: 5 November 2019

check for updates

\begin{abstract}
With rapidly ageing populations, the world is experiencing unsustainable healthcare from chronic diseases such as metabolic, cardiovascular, neurodegenerative, and cancer disorders. Healthy diet and lifestyle might contribute to prevent these diseases and potentially enhance health outcomes in patients during and after therapy. Fermented dairy foods (FDFs) found their origin concurrently with human civilization for increasing milk shelf-life and enhancing sensorial attributes. Although the probiotic concept has been developed more recently, FDFs, such as milks and yoghurt, have been unconsciously associated with health-promoting effects since ancient times. These health benefits rely not only on the occurrence of fermentation-associated live microbes (mainly lactic acid bacteria; LAB), but also on the pro-health molecules (PHMs) mostly derived from microbial conversion of food compounds. Therefore, there is a renaissance of interest toward traditional fermented food as a reservoir of novel microbes producing PHMs, and "hyperfoods" can be tailored to deliver these healthy molecules to humans. In FDFs, the main PHMs are bioactive peptides (BPs) released from milk proteins by microbial proteolysis. BPs display a pattern of biofunctions such as anti-hypertensive, antioxidant, immuno-modulatory, and anti-microbial activities. Here, we summarized the BPs most frequently encountered in dairy food and their biological activities; we reviewed the main studies exploring the potential of dairy microbiota to release BPs; and delineated the main effectors of the proteolytic LAB systems responsible for BPs release.
\end{abstract}

Keywords: fermented dairy food; bioactive peptides; Lactobacillus; Lactococcus; Streptococcus; antihypertensive peptides; antioxidant peptides; anti-microbial peptides; anti-diabetic peptides; proteolytic system

\section{Introduction}

The promotion of healthy and sustainable diets is one of major actions prioritized in European research agenda for supporting public health and citizens' wellbeing. Several evidences proved that some foods or food ingredients, including living microbial cells contained therein, can enhance short-term wellbeing and reduce initiation and/or progression of non-diseases and the associated chronic conditions (e.g., musculoskeletal disorders, cardiovascular diseases and stroke, hypertension, obesity, type II diabetes mellitus (T2D), cancers, or mental health conditions) [1,2]. In view of the importance of nutrition in health promotion, academia and the food industry face the new challenge to tailor novel strategies and products that better contribute to human welfare as well as reducing the risk of insurgence of specific pathologies [3]. The term "functional food," was coined in Japan and the USA in the 1970s, to indicate food products fortified with special constituents that possess advantageous physiological effects supported in vitro and in vivo [4]. Generally, functional food is 
deprived of some "dangerous" components, such as salt, sugars, and saturated fat levels, and/or is enriched in probiotic cells and/or pro-health molecules (PHMs). Although functional foods are not defined legally, scientific literature regarding these products is increasing to demonstrate that they provide additional benefits beyond the nutrient intake and the hunger satisfaction [5,6]. However, much more effort should be done yet to identify PHMs and to elucidate their multiple mechanisms of action in the food-human consortium. This knowledge is essential to design a novel generation of functional food with the maximally positive health impact, the so-called "hyperfood" (Figure 1) [7].

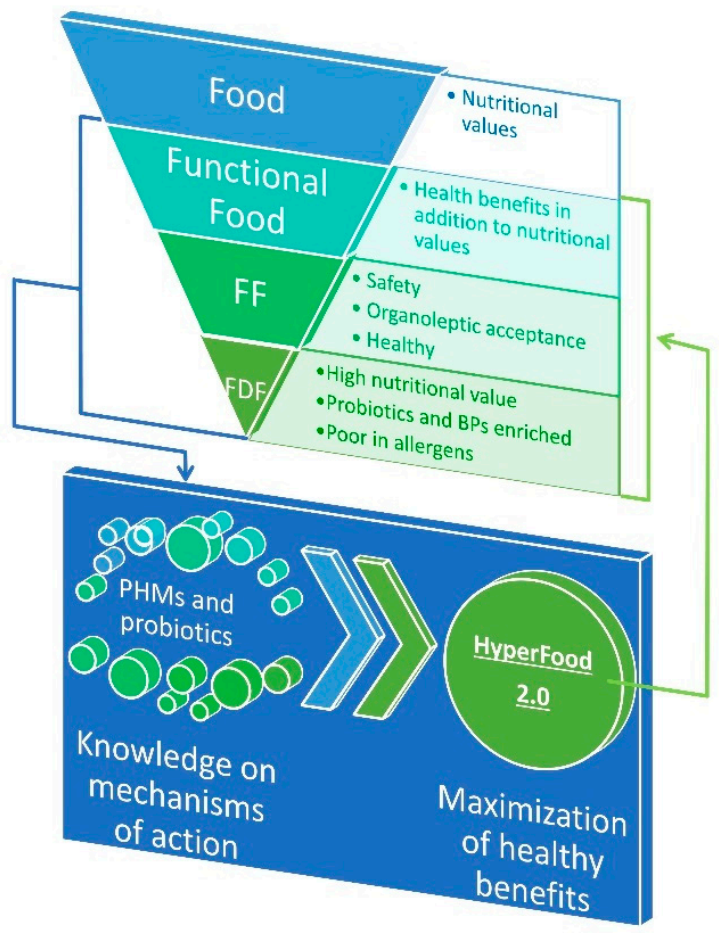

Figure 1. Position of fermented dairy food (FDF) in food consortium and strategies for knowledge-driven optimization of a novel generation of functional food, called HyperFood 2.0. Abbreviations: FF, fermented food; FDF, fermented dairy food; BPs, bioactive peptides; PHMs, pro-health molecules.

Food fermentation is generally defined as the microbial conversion of food macro- and micro-compounds under anaerobic conditions. Since the early phases of civilization, mankind unconsciously utilized microbes for preserving food and enhancing flavors, aromas, and textures $[7,8]$. Repetition of these practices over thousands of years lead to the adaptation of microorganisms to food ecosystems [9]. Today, one-third of the human diet worldwide still consists of fermented foods and beverages (generally referred as FF) [10]. In industrializing countries, well-established fermentation processes, involving selected starter cultures or microbial consortia, assure safety and organoleptic properties highly appreciated by consumers. However, FF produced by indigenous microbiota or back-slopping procedure still remains relevant in artisanal segments of the market both in Western and in Eastern countries. Association between FF and health dated back from ancient Greek, when Hippocrates formulated the concept of "food as medicine". Fermented dairy food (FDF) is a generic term used to define three main types of dairy food matrices obtained through lactic fermentation by lactic acid bacteria (LAB): Liquid (fermented milks), semi-solid (yogurt and some fresh cheeses), and solid (the majority of cheeses). FDFs have been the paradigm of healthy food since Metchnikoff's studies [11-14] (Figure 1). Recently, randomized controlled trials, prospective cohort studies, and meta-analyses supported an inverse relation between consumption of FDFs and overweight [15-18] or risk of metabolic syndrome [19,20], cardiovascular disease [21-23], T2D [24-26], and overall mortality [27]. These data should be considered with caution for at least three reasons: the variety of dairy products considered can be a confounding element, which biases inter-studies 
comparison; dosage has not been harmonized across different experimental cohorts; and the impact of other factors, such as gender and age, has not been considered. Nevertheless, these evidences encourage the uptake of FDF and promote the search for molecular effectors underpinning FDFs-associated healthy benefits, which, in turn, can drive the translation towards more reliable health benefits for improved FDF.

In case of FDF, milk itself provides a large number of beneficial compounds. According to the consensus document published in May 2017 by a panel of 18 experts, these PHMs include proteins, minerals (calcium, phosphorus, and magnesium), water-soluble vitamins (B12 and riboflavin), fat-soluble vitamins (A, D, and K2), and specific bioactive lipids [28]. In addition to these nutritional attributes, fermentation processes provide other promoting healthy effects. FDF delivers specifically selected or indigenous probiotic microbes into the human intestine, where they may modulate immune response, enhance epithelial barrier function, or modify indigenous gut microbiota [29,30]. Furthermore, during lactic fermentation certain potentially "dangerous" compounds are depleted by microbial conversion, e.g., degradation of allergenic $\alpha$-lactalbumin and $\beta$-lactoglobulin into oligopeptides or fermentation of lactose into lactic acid [31]. Finally, microbes can release secondary metabolites, which act as PHMs in human body [32].

Several reviews revised different pro-health aspects of milk and FDF as well as their role as carrier for probiotics [33-38]. Here, we focused on bioactive peptides (BPs), the most relevant PHMs released from milk proteins by the action of LAB inhabiting FDF. We summarized the most compelling evidences on how FDFs are bio-reservoirs of novel BPs-producing LAB and highlighted how their usage is relevant in developing novel functional food with maximized amount of BPs through an approach referred to as reverse food engineering.

\section{Survey of BPs in FDF}

BPs are peculiar protein fragments that modulate various regulatory processes at different levels in the human body, such as digestive, immune, cardiovascular, endocrine, and nervous systems, ultimately influencing human health $[39,40]$. To date, milk caseins are viewed as the most important source of BPs and products containing milk-derived peptides have an increasing market trend (Table 1). Although exogenous enzymes or proteolysis during gastro-intestinal (GI) transit can also release BPs, we only focused on BPs produced by LAB proteolysis.

Numerous BPs are detected in FF and are reported as important agents for different functional activities such as antioxidative, antihypertensive, antimicrobial, immunomodulatory, opioid, hypocholesterolemic, mineral binding, and bone mineralization activities.

To attend the above-mentioned effects in vivo, these BPs should reach intact the target site, and thus remain active after oral ingestion and during GI digestion and absorption [41,42]. This implies resistance to enzymatic hydrolysis by gastric and intestinal proteases and peptidases laying along the brush border membrane of the villi. When absorbed, short peptides (usually di- and tripeptides) are transported across intestinal enterocytes via a specific peptide transport system (PepT1), whereas largest peptides are likely absorbed by transcellular or paracellular mechanisms or via endocytosis [41,43]. Nonetheless, there are substantial evidences indicating the absorption of bioactive peptides in humans and animals, in some cases reaching blood concentrations of few $\mu$ molar [41-44]. Since the bioavailability of BPs is a relevant but often poorly explored point, in this survey we detailed whether there are in vivo evidences of healthy action for every potential BPs. 
Table 1. Principal milk-derived products containing bioactive peptides (BPs) currently available.

\begin{tabular}{|c|c|c|c|c|}
\hline Brand & Category & Producers & Molecules & Bioactivities \\
\hline BioPURE-GMP & Whey protein isolate & Davisco, USA & $\mathrm{k}$-casein $\mathrm{f}(106-109)$ & $\begin{array}{l}\text { Satiety regulation, anti-carcinogenic, } \\
\text { antimicrobial, anti-thrombotic BPs }\end{array}$ \\
\hline BioZate & Whey protein isolate & Davisco, USA & $\beta$-lactoglobulin fragments & Hypotensive BPs \\
\hline C12 Peption & Ingredients & DMV, The Netherlands & Casein derived FFVAPFPEVFGK & Hypotensive BP \\
\hline Capolac & Ingredients & Arla Food, Denmark & Casein phosphopeptide & Mineral absorption \\
\hline Casein DP/Peptio Drink & Soft milk drink & Kracie Pharmaceuticals, Japan & Casein derived FFVAPFPEVFGK & Hypotensive \\
\hline CЕ90СРP & Ingredients & DMV, The Netherlands & Casein phosphopeptide & Mineral absorption \\
\hline PeptoPro & Flavored drink & DSM Food specialties, The Netherlands & Casein phosphopeptide & Improves muscle performance \\
\hline Cysteine peptide & Ingredients/hydrolysate & DMV, The Netherlands & Casein peptides & hypotensive BPs \\
\hline Praventin & Capsule & DMV, The Netherlands & Lactoferrin-enriched whey protein hydrolysate & Antimicrobial BPs (reduced skin infection) \\
\hline Festivo & Low-fat cheese & MIT Agrifood Research, Finland & $\alpha S 1$-casein $\mathrm{f}(1-6), \alpha S 1$-casein $\mathrm{f}(1-7), \alpha$ S1-casein $\mathrm{f}(1-9)$ & Hypotensive BPs \\
\hline Kotsu Kotsu calcium & Soft drink & Asahi Soft Drink & Casein phosphopeptide & Mineral absorption \\
\hline Evolus & Fermented milk & Valio Ltd. Finland & VPP, IPP & Hypotensive BPs \\
\hline Calpis/Ameal S 120 & Sour milk & Calpis Co Ltd, Japan & VPP, IPP & Hypotensive BPs \\
\hline Ameal S & Tablet & Calpis Co Ltd, Japan & VPP, IPP & Hypotensive BPs \\
\hline Immunel & Ingredient & Wild Co., Germany & Milk peptides & Anti-inflammatory BPs \\
\hline Tegricel & Ingredient & Wild Co., Germany & Milk peptides & Anti-inflammatory BPs \\
\hline Lactium/ProDiet F200 & Flavored milk drink/capsules & Ingredia, France & $\alpha$ S1-casein $\mathrm{f}(91-100)$ YLGYLEQLLR & Stress relief BPs \\
\hline Vivinal Alpha & Ingredient & Borculo Domo Ingredients & $\alpha$-lactalbumin-rich whey protein hydrolysate & Aids relaxation and sleep \\
\hline Dermylex & Tablet & Advitech Inc., Canada & Whey protein extract XP-828L & Reduces symptoms of psoriasis \\
\hline Capolac & Ingredient & Arla Food Ingredients & Casein phosphopeptide & Mineral absorption \\
\hline Recaldent & Chewing gum & Cadbury Enterprises & Calcium casein peptone-calcium phosphate & Anticariogenic BPs \\
\hline
\end{tabular}




\subsection{Anti-Hypertensive Peptides Identified in Commercial FDFs}

As suggested by the European Society of Cardiology (ESC) working group on cardiovascular pharmacology and drug therapy, the nutraceutical approach for hypertension management could bring positive effects for those patients with blood pressure borderline values and may be co-administered with anti-hypertensive drugs in blood pressure reduction [45,46].

In recent years, scientists have investigated various BPs derived from FDFs, such as fermented milk, yogurt, and cheese, for their potential anti-hypertensive activity (Table 2) [40,47,48]. Different mechanisms of action were suggested to describe their anti-hypertensive effects [40,47]. The most important mechanism by which BPs may decrease blood pressure is through ACE inhibition $[49,50]$.

Table 2. Peptides with in vivo anti-hypertensive activity identified in commercial FDFs.

\begin{tabular}{|c|c|c|c|c|c|c|}
\hline Peptide & Fragment & Source & $\begin{array}{l}\text { In vivo } \\
\text { Model }\end{array}$ & Dose & $\begin{array}{l}\text { Systolic } \\
\text { Blood } \\
\text { Pressure } \\
\text { Reduction }\end{array}$ & References \\
\hline $\mathrm{VPP}^{1}$ & $\begin{array}{l}\beta \text {-casein } \\
\mathrm{f}(84-86)\end{array}$ & $\begin{array}{l}\text { Fermented milk, cheese, } \\
\text { yogurt }\end{array}$ & $\begin{array}{l}\text { Huma } \\
\text { SHR }\end{array}$ & $\begin{array}{c}3-100 \\
\mathrm{mg} / \mathrm{day} \\
5 \mathrm{mg} / \mathrm{kg}\end{array}$ & $\begin{array}{l}-3.73 \mathrm{mmHg} \\
-20.1 \mathrm{mmHg}\end{array}$ & {$[23,51-58]$} \\
\hline $\mathrm{IPP}^{1}$ & $\begin{array}{l}\beta \text {-casein } \\
\mathrm{f}(74-76) \\
\mathrm{K} \text {-casein } \\
\mathrm{f}(108-110)\end{array}$ & $\begin{array}{l}\text { Fermented milk, cheese, } \\
\text { yogurt }\end{array}$ & $\begin{array}{l}\text { Human } \\
\text { SHR }\end{array}$ & $\begin{array}{l}3-100 \\
\mathrm{mg} / \mathrm{day} \\
5 \mathrm{mg} / \mathrm{kg}\end{array}$ & $\begin{array}{l}-3.73 \mathrm{mmHg} \\
-18.3 \mathrm{mmHg}\end{array}$ & {$[23,51-58]$} \\
\hline YP & $\begin{array}{l}\text { Various fragments in } \\
\beta \text {-casein, } \alpha S 1 \text {-casein, } \kappa \text {-casein }\end{array}$ & Cheese, yogurt & SHR & $1 \mathrm{mg} / \mathrm{kg}$ & $-27.4 \mathrm{mmHg}$ & {$[55,59,60]$} \\
\hline TKVIP & $\alpha \mathrm{S} 2$-casein $\mathrm{f}(198-202)$ & Yogurt & SHR & $1 \mathrm{mg} / \mathrm{kg}$ & $-9.2 \mathrm{mmHg}$ & {$[55,61]$} \\
\hline KVLPVPQ & $\beta$-casein A2 f(169-175) & Cheese, yogurt & SHR & $2 \mathrm{mg} / \mathrm{kg}$ & $-31.5 \mathrm{mmHg}$ & {$[55,61]$} \\
\hline LHLPLP & $\beta$-casein A2 f(133-138) & Cheese, yogurt & SHR & $3 \mathrm{mg} / \mathrm{kg}$ & $-25.3 \mathrm{mmHg}$ & {$[53-55,62]$} \\
\hline RYLGY & $\alpha \mathrm{S} 1$-casein $\mathrm{f}(90-94)$ & Cheese & SHR & $5 \mathrm{mg} / \mathrm{kg}$ & $-25 \mathrm{mmHg}$ & {$[53,54,63,64]$} \\
\hline AYFYPEL & $\alpha$ S1-casein $\mathrm{f}(143-149)$ & Cheese & SHR & $5 \mathrm{mg} / \mathrm{kg}$ & $-20 \mathrm{mmHg}$ & {$[53,54,63]$} \\
\hline RYLG & $\alpha$ S1-casein $\mathrm{f}(90-93)$ & Cheese & SHR & $5 \mathrm{mg} / \mathrm{kg}$ & $-18 \mathrm{mmHg}$ & {$[53,54,64]$} \\
\hline RY & $\begin{array}{l}\text { Various fragments in } \\
\alpha \mathrm{S} 1 \text {-casein, } \alpha \mathrm{S} 2 \text {-casein, } \\
\text { K-casein }\end{array}$ & Fermented milk & SHR & $5 \mathrm{mg} / \mathrm{kg}$ & $-18 \mathrm{mmHg}$ & {$[64,65]$} \\
\hline HLPLP & $\beta$-casein A2 f(134-138) & Cheese & SHR & $7 \mathrm{mg} / \mathrm{kg}$ & $-23.5 \mathrm{mmHg}$ & {$[53,54,66]$} \\
\hline LPLP & $\beta$-casein A2 f(135-138) & Yogurt & SHR & $7 \mathrm{mg} / \mathrm{kg}$ & $-16 \mathrm{mmHg}$ & {$[55,67]$} \\
\hline PLP & $\begin{array}{l}\beta \text {-casein A2 f(136-138) } \\
\text { Various fragments in }\end{array}$ & Cheese & SHR & $7 \mathrm{mg} / \mathrm{kg}$ & $-21.2 \mathrm{mmHg}$ & {$[59,67]$} \\
\hline $\mathrm{FP}$ & $\begin{array}{c}\beta \text {-casein, } \alpha \mathrm{S} 1 \text {-casein, } \\
\alpha \mathrm{S} 2 \text {-casein }\end{array}$ & Cheese, yogurt & SHR & $8 \mathrm{mg} / \mathrm{kg}$ & $-27 \mathrm{mmHg}$ & {$[55,58,59,68]$} \\
\hline LVYPFTGPIPN & $\begin{array}{l}\beta \text {-casein caprine } \\
\mathrm{f}(58-68)\end{array}$ & Kefir & SHR & $10 \mathrm{mg} / \mathrm{kg}$ & $-28 \mathrm{mmHg}$ & {$[66,69]$} \\
\hline VRGPFPIIV & $\begin{array}{c}\beta \text {-casein } \\
\mathrm{f}(201-209)\end{array}$ & Yogurt & SHR & $10 \mathrm{mg} / \mathrm{kg}$ & $-16 \mathrm{mmHg}$ & {$[55,62]$} \\
\hline KKYNVPQL & $\begin{array}{l}\alpha S 1 \text {-casein caprine } \\
\mathrm{f}(102-109)\end{array}$ & Cheese & SHR & $10 \mathrm{mg} / \mathrm{kg}$ & $-11.5 \mathrm{mmHg}$ & {$[48,58,66]$} \\
\hline AVPYPQR & $\begin{array}{c}\beta \text {-casein } \\
\mathrm{f}(177-183)\end{array}$ & Kefir & SHR & $100 \mathrm{mg} / \mathrm{kg}$ & $-10 \mathrm{mmHg}$ & {$[70,71]$} \\
\hline RPKHPIKHQ & $\begin{array}{l}\alpha \mathrm{S} 1 \text {-casein } \\
\mathrm{f}(1-9)\end{array}$ & Cheese & SHR & n.a. & $-9.3 \mathrm{mmHg}$ & {$[48,58,72]$} \\
\hline TPVVVPPFLQP & $\begin{array}{l}\beta \text {-casein } \\
\mathrm{f}(80-90)\end{array}$ & Cheese, yogurt & SHR & n.a. & $-8 \mathrm{mmHg}$ & {$[55,59,68]$} \\
\hline YPFPGPIPN & $\beta$-casein A2 $f(60-68)$ & Cheese, kefir & SHR & n.a. & $-7 \mathrm{mmHg}$ & {$[48,58,72,73]$} \\
\hline
\end{tabular}

Additional described mechanisms involve an increase in the production of the vasodilating endothelial nitric oxide (NO) as well as the inhibition of renin. Furthermore, BPs can also induce vasodilatation by reducing the activity of the sympathetic system [74].

Among the anti-hypertensive peptides found in FDFs, the lactotripeptides, VPP and IPP, gained great attention in recent years thanks to their increasingly frequent commercial use in hypotensive milk-drinks production. Indeed, numerous in vivo studies reported a blood pressure reduction in mildly hypertensive patients $[23,51,75,76]$. These lactotripeptides were initially detected in a sample of Japanese sour milk fermented by Lactobacillus helveticus and Saccharomyces cerevisiae and characterized for their ACE-inhibitory (ACE-i) activity and hypotensive effect in spontaneously hypertensive rats $[52,77]$. Next, VPP and IPP have been found in milk fermented by other LAB such as Lactobacillus 
casei, Lactobacillus delbrueckii, and Lactobacillus rhamnosus as well as in commercial yogurt and several cheeses at physiological relevant concentrations [53-55,78-82]. It is worth mentioning that VPP and IPP have been also detected in physiologically relevant amounts after in vitro GI digestion of milk from different species [83-86].

In vivo effect of IPP and VPP on blood pressure in pre-hypertensive and hypertensive subjects has been recently described in numerous meta-analysis of randomized clinical trials and reviews [23,40,51,56]. Two meta-analyses of 18 and 30 placebo-controlled clinical trials found a pooled effect of lactotripeptides on systolic blood pressure reduction of $-3.73 \mathrm{mmHg}$ and $-2.95 \mathrm{mmHg}$, respectively $[23,51]$. Sub-group analyses demonstrated that the decrease in systolic blood pressure in an Asian population was significantly greater (from -5.54 to $-6.93 \mathrm{mmHg}$ ), compared with a European population (from -1.28 to $-1.36 \mathrm{mmHg}$ ) [23,51,56,57]. Interestingly, the effect was more evident in hypertensive subjects and smaller doses (from 3 to $10 \mathrm{mg} /$ day) had higher blood pressure reduction than larger dose $[23,56,59,87]$.

Several BPs identified in commercial FDFs have demonstrated in vivo anti-hypertensive activity in spontaneously hypertensive rats (SHR) (Table 2). YP showed a potent anti-hypertensive activity in SHR decreasing the systolic blood pressure of $-27.4 \mathrm{mmHg}$ with a dosage of $1 \mathrm{mg} / \mathrm{kg}$ with respect to VPP and IPP, which showed a systolic blood pressure decreasing effect in SHR of -20.1 and -18.3 $\mathrm{mmHg}$, respectively, at doses of $5 \mathrm{mg} / \mathrm{kg}[52,60]$. Maeno et al. [61] isolated and identified the peptide responsible for the anti-hypertensive effect of a casein hydrolysate produced by L. helveticus CP790 proteinase. The purified peptide KVLPVPQ, further isolated in a commercial functional yogurt, had potent anti-hypertensive effects $(-31.5 \mathrm{mmHg})$ in SHR at a dosage of $2 \mathrm{mg} / \mathrm{kg}$ [55,61]. It is important to underline that both the above described peptides displayed very low in vitro ACE-i activity, which was about 80-200 times lower than that of the lactotripeptides VPP and IPP (Table 2). These observations suggest that the assessment of the in vitro ACE-inhibitory activity of a peptide is not enough to predict or guarantee an in vivo anti-hypertensive effect [88]. This is also supported by the evidence that some BPs with very high in vitro ACE-i activity failed to exert an anti-hypertensive effect when administered to SHR [88].

The reasons for this issue could be related to (i) the resistance or susceptibility of the BPs to the hydrolysis by GI proteases, (ii) their absorption into the blood stream, and (III) different mechanisms of action other than ACE-inhibition.

Nevertheless, other peptides identified in FDFs, such as LHLPLP, RYLGY, and AYFYPEL, appeared to be potent ACE inhibitors and able to decrease systolic blood pressure in SHR even more than IPP and VPP $[62,63]$. The peptide LHLPLP was found in several cheeses such as Parmigiano Reggiano, Grana Padano, Cheddar, and Gorgonzola [53,54]. Interestingly, this peptide was easily released during in vitro GI digestion of Parmigiano Reggiano and Grana Padano cheeses, reaching concentration, which can show an in vivo effect $[53,54]$. Indeed, LHLPLP is in vitro hydrolyzed by cellular peptidases to the pentapeptide HLPLP, which still displayed high anti-hypertensive effect in SHR suggesting that this peptide is the active form of LHLPLP [66,89]. Similarly, after in vitro GI digestion, 93\% of the peptide RYLGY was hydrolyzed in minor fragments, which showed anti-hypertensive activity in SHR as high as the intact parent peptide [64].

In addition, numerous ACE-i peptides have been identified in FDFs such as cheeses, yogurt, fermented milk, and kefir. Even though confirmatory studies in SHR have not yet carried out, some of these peptides exhibited low or very low $\mathrm{IC}_{50}$ values. For example, the dipeptides IW and WL showed $\mathrm{IC}_{50}$ values of 0.7 and $10 \mu \mathrm{mol} / \mathrm{L}$, are bioavailable in humans, and were able to reduce in vivo ACE activity, appearing to be excellent candidates for further in vivo studies [90]. Furthermore, the ACE-i $\beta$-casein-derived peptides YQEPVLGPVRGPFPIIV and QEPVLGPVRGPFPIIV have been detected in plasma of human subjects after a cheese-enriched diet [44].

The complete list of ACE-i peptides together with the fermented food sources can be found in the online Supplementary Materials (Table S1). 


\subsection{Antioxidant Peptides Identified in Commercial Fermented Dairy Products}

The side effects of oxidation in the body and in foodstuffs is well reported and studied. Excessive free radicals and other reactive oxygen species may affect the food quality, bringing out a range of defects such as unacceptable taste and flavor and prejudicing the shelf life [32,91]. In addition, it has been recognized a relation between age-related diseases and the presence of oxidative damages. The lipid hydroperoxides and low molecular weight compounds arising from oxidative reactions are considered the causative factors involved in these diseases. Evidences of significant free radical mediated injury to several pathological conditions are widely reported in scientific literature, including neurodegenerative disorders, atherosclerosis, diabetes, inflammatory processes, rheumatoid arthritis, and cancer [92-100]. The opportunity to reduce oxidative stress in the body through the daily intake of antioxidants, for example antioxidative peptides, may be of pivotal interest and an attractive strategy to reduce inflammatory conditions mediated by radical oxygen species (ROS) in the living cells.

Milk and dairies, as widely consumed products, are thoroughly investigated for their physiological and biochemical functions. They contain a wide range of biologically active compounds in varying proportions depending on the animal species (i.e., bovine, buffalo, goat, sheep, and camel), matrix type (i.e., milks, cheeses, fermented milks, and yogurts), and manufactural processes (i.e., mechanical, heating, and fermentative). This class of active compounds include both hydrophilic and lipophilic antioxidants such as proteins (specifically casein), small peptides, coenzyme Q10, vitamins (A, C, E, and D3), carotenoids, some minerals, and elements in trace [101,102]. Cichosz et al. [101] found that milk antioxidants synergistically worked by forming an antioxidant network, improving the antioxidant ability of milk, and protecting milk itself and its fat fraction against the oxidation phenomena. Moreover, these molecules can be involved on important effects on host metabolism and health [32,103].

Recently, current research is focused on food-derived peptides and emerging evidence confirmed their strong role in the prevention of oxidative damages. Nevertheless, milk products and fermented milks are recognized as the most common dietary sources of food antioxidants. Indeed, milk proteinderived BPs gained great interest and began to be regarded as a novel class of antioxidants. In particular, ripened chesses (Swiss cheese varieties, Cheddar, Manchego, and Gouda), fermented milks, and yogurts became the subject for numerous studies, which confirmed these products among the major sources of BPs [80,104-106].

Most of the BPs are encrypted in the caseins sequences [48]. Such small motifs are non-active when present in the original proteins but can be liberated after the hydrolysis of protein during GI digestion, microbial fermentation, or enzymatic hydrolysis [39,107]. Parella et al. [108] suggested the idea that antioxidant peptides might be released after a mild heat treatment of milk during cheese manufacturing. The complexity of the production process of FDFs lies in the cheese ripening and proteolysis, identified as the crucial phases for antioxidants formation. In fact, antioxidant peptides are mostly produced by the action of proteases and peptidases released from both starter and non-starter LAB [109-112], residual rennet enzymes, and indigenous milk enzymes such as plasmin [113,114]. Caseins are characterized by a high content of $\mathrm{H}, \mathrm{P}$, and $\mathrm{Y}$, widely known for their free radical scavenger activity [115]. Their presence in peptides is a determinant factor in the antioxidant effect [116]. In fact, free radicals are deactivated by peptides containing hydrophobic and aromatic amino acids (such as $\mathrm{Y}, \mathrm{H}, \mathrm{P}, \mathrm{W}$ ) and selected free amino acids ( $\mathrm{Y}$ and $\mathrm{C}$ ) $[101,117]$. In particular, the presence of $\mathrm{Y}$ and $\mathrm{W}$ residues in the peptides sequences is considered essential for a significant increase of the antioxidant effect, because of its strong ability to donate a proton $[65,118,119]$. Actually, their occurrence into the sequences of dipeptides is usually recognized as responsible for antioxidant activities [120]. Histidine displays its antioxidant effects by scavenging free radical species, absorbing active oxygen or through metal ions chelation. Chen et al. [121] described $\mathrm{H}$ and $\mathrm{P}$ as the most important residues in peptides isolated from a soybean hydrolysate for their inhibitory effect of lipoprotein peroxidation. Kitts and Weiler [122] also reported that the presence of a P or an L residue at the N-terminus position of a $\mathrm{HH}$ dipeptide could improve antioxidant activity as well as promote a synergistic effect with other non-peptide antioxidants. Furthermore, M and C, as efficient sulphur hydrogen donators, are 
particularly active in quenching free radical species [116,123]. Several studies also confirmed how crucial it is the position of the amino acid residues in the peptide sequence.

The kefir peptides VYPFPGPIPN and QEPVLGPVRGPFPIIV were identified by Eisele et al. [124] as strong antioxidative peptides and weak ACE inhibitors. Other peptide sequences identified in commercial dairy products had previously been described as antioxidant BPs (Table 3). Fragments with the amino acid sequence VKEAMAPK, VLPVPQK, and VPYPQ, obtained from cheddar cheese, milk fermented with L. rhamnosus, and yogurt, respectively, exhibited antioxidant activity [125-127]. In addition, the $\beta$-casein peptide KVLPVPQ detected in sour milk by Hernandez-Ledesma et al. [119] showed antioxidant activity as occurs with peptide VLPVPQ, previously described by Rival et al. [126]. The octapeptide SKVLPVPQ, isolated and identified in two commercial Spanish fermented milks produced with L. helveticus and S. cerevisiae, exhibited antioxidant activities [128]. A peptide composed of nine amino acids KIHPFAQTQ isolated from $\beta$-casein of buffalo's yogurt has proven to be particularly effective in antioxidant effects [129]. A total of 187 BPs derived from $\beta$-casein, $\alpha$ S1-casein, and $\alpha$ S2-casein were detected in cheeses by Pisanu et al. [130]. Among these, nine displayed a strong antioxidant activity, originated from the degradation of $\beta$-casein, specifically from the fragment $f$ (194-208), QEPVLGPVRGPFPIL.

Table 3. Peptides with antioxidant and antimicrobial activities identified in commercial fermented dairy products.

\begin{tabular}{|c|c|c|c|}
\hline Peptide & Fragment & Source & References \\
\hline ARHPHPHLSFM • & K-casein $\mathrm{f}(96-106)$ & Yogurt & {$[55,129]$} \\
\hline AVPYPQR * & $\beta$-casein $f(177-183)$ & Kefir & {$[70,126]$} \\
\hline AYFYPE • & $\alpha$ S1-casein f(143-148) & Yogurt, cheese & {$[55,64]$} \\
\hline AYFYPEL • & $\alpha$ S1-casein f(143-149) & Cheese & {$[53,54,64]$} \\
\hline EMPFPK $\mathbf{\square}$ & $\beta$-casein $\mathrm{f}(108-113)$ & Yogurt & [55] \\
\hline EVFGKEKVN $\mathbf{\square}$ & $\alpha \mathrm{S} 1$-casein $\mathrm{f}(30-38)$ & Kefir & {$[70,131]$} \\
\hline FALPQYLK• & as2-casein $\mathrm{f}(174-181)$ & Kefir & {$[70,132]$} \\
\hline FSDKIAKYIPIQ घ & K-casein $\mathrm{f}(18-29)$ & Yogurt & [55] \\
\hline GPVRGPFPII • & $\beta$-casein $\mathrm{f}(199-208)$ & Fermented milk, yogurt & {$[119,127]$} \\
\hline HLPLPL • & $\beta$-casein $\mathrm{f}(133-138)$ & Yogurt, fermented milk & {$[55,105]$} \\
\hline IPIQY•• & $\mathrm{k}$-casein $\mathrm{f}(26-32)$ & Yogurt & [127] \\
\hline IPIQYVL • & $\kappa$-casein $\mathrm{f}(26-30)$ & Fermented milk & [119] \\
\hline KAVPYPQ • & $\beta$-casein $f(176-182)$ & Yogurt & [127] \\
\hline KIHPFAQTQ • & $\beta$-casein $\mathrm{f}(48-56)$ & Yogurt & {$[133,134]$} \\
\hline KVLPVPQ • & $\beta$-casein $f(169-175)$ & Fermented milk & [119] \\
\hline KVLPVPQK• & $\beta$-casein $f(169-176)$ & Fermented milk & {$[105,126]$} \\
\hline LQDKIHP • & $\beta$-casein $f(45-51)$ & Yogurt & [134] \\
\hline PYVRYL * & as2-casein $\mathrm{f}(203-208)$ & Kefir & [132] \\
\hline QEPVLGPVRGPFPII • & $\beta$-casein $\mathrm{f}(194-208)$ & Yogurt & [127] \\
\hline QQPVLGPVRGPFPIIV • & $\beta$-casein $\mathrm{f}(194-209)$ & Yogurt & [127] \\
\hline RDMPIQ • & $\beta$-casein $\mathrm{f}(183-188)$ & Fermented milk & {$[105,134]$} \\
\hline RPKHPIK $\mathbf{\square}$ & $\alpha \mathrm{S} 1$-casein $\mathrm{f}(1-7)$ & Cheese & {$[58]$} \\
\hline RPKHPIKHQGLPQEVLNENLLRF $\boldsymbol{\square}$ & $\alpha \mathrm{S} 1$-casein $\mathrm{f}(1-23)$ & Kefir & {$[70]$} \\
\hline $\mathrm{RY} \bullet$ & $\begin{array}{c}\text { Various fragments in } \alpha \mathrm{S} 1 \text {-casein, } \\
\alpha \mathrm{S} 2 \text {-casein, } \mathrm{K} \text {-casein }\end{array}$ & Fermented milk, cheese & {$[53,119]$} \\
\hline RYLG• & $\alpha S 1$-casein $\mathrm{f}(90-93)$ & Cheese & {$[53,54,64]$} \\
\hline RYLGY• & $\alpha \mathrm{S} 1$-casein $\mathrm{f}(90-94)$ & Cheese & {$[53,54,64]$} \\
\hline SDIPNPIGSENSE $\boldsymbol{\square}$ & $\alpha$ S1-casein $\mathrm{f}(180-192)$ & Kefir & [70] \\
\hline SKVLPVPQ • & $\beta$-casein $\mathrm{f}(168-175)$ & Fermented milk drinks & [128] \\
\hline STVATL $\mathbf{\square}$ & $\mathrm{K}$-casein $\mathrm{f}(141-146)$ & Yogurt & [55] \\
\hline TVQVTSTAV $\mathbf{\square}$ & $\mathrm{K}$-casein $\mathrm{f}(161-169)$ & Yogurt & [55] \\
\hline VKEAMAPK•• & $\beta$-casein $f(98-105)$ & Fermented milk, cheese & {$[105,125,126]$} \\
\hline VLNENLLR $\mathbf{~}$ & $\alpha \mathrm{S} 1$-casein $\mathrm{f}(15-22)$ & Kefir & [70] \\
\hline VLPVPQK * & $\beta$-casein $f(170-176)$ & Fermented milk & {$[105,126]$} \\
\hline VPYPQ• & $\beta$-casein $\mathrm{f}(178-182)$ & Yogurt & [127] \\
\hline VYPFPGPIPN • & $\beta$-casein A2 f(59-68) & Kefir & {$[70,124]$} \\
\hline YQEPVLGPVRGPFPI ם & $\beta$-casein $f(191-205)$ & Kefir & {$[70]$} \\
\hline YQEPVLGPVRGPFPIIV* & $\beta$-casein $f(191-207)$ & Kefir & [124] \\
\hline YVL $\square$ & $\mathrm{K}$-casein $\mathrm{f}(30-32)$ & Yogurt & [55] \\
\hline
\end{tabular}

- means antioxidant peptide; $\boldsymbol{\square}$ means antimicrobial peptide; ${ }^{*}$ means antioxidant and antimicrobial peptide. 
In conclusion, FDFs may be a rich source of natural antioxidants, which can be consumed or used as natural ingredients to develop functional foods that may enhance the biological value and preservation of food products as well as the healthy conditions of the consumer [122,135-137]. This ability of peptides to inhibit oxidative phenomena by binding or interacting with radicals and transition metals could be a boon to boost human health, although in vivo animal studies and human trials confirming these effects are necessary.

\subsection{Anti-microbial Peptides Identified in Commercial Fermented Dairy Products}

Another interesting property of milk-derived BPs is related to their antimicrobial effect. These peptides show different amino acid composition and mechanism of action. For example, it has been proposed that kappacin form an amphipathic $\alpha$-helix structure in the space allowing the formation of an anionic pore, increasing the permeability of the membrane of the bacteria [138]. The antimicrobial $\alpha$ S2-casein-derived peptide VYQHQKAMKPWIQPKTKVIPYVRYL was able to permeabilize the inner and outer membrane of Escherichia coli and Staphylococcus carnosus by initially binding lipopolysaccharide or lipotechoic acid, respectively [139].

Most of the antimicrobial peptides originated from commercial FDFs have been identified in cheeses, yogurt, and kefir (Table 3). The ability of LAB found in fermented dairy products to generate anti-microbial peptides from milk protein hydrolysis may confer a competitive advantage, thus reducing the growth and survival of food-borne pathogens [140].

Kunda et al. [55] found five different antimicrobial peptides in a functional commercial yogurt. Moreover, Dallas et al. [70] identified six antimicrobial peptides released by LAB in kefir. Among them, LAB population in kefir was able to release the antimicrobial peptide isracidin (RPKHPIKHQGLPQEVLNENLLRF) corresponding to the $\alpha$ S1-casein fragment $1-23$. This peptide was also identified in Coalho cheese [141] and was able to protect in vivo mice from Listeria monocytogenes, Streptococcus pyogenes, and Staphylococcus aureus infections [142].

Some of the reported peptides displayed bactericidal activity against both Gram-positive and Gram-negative bacteria. For example, the peptides YVL and PYVRYL, respectively isolated from commercial yogurt and kefir, resulted as in vitro growth inhibitors of the Gram-negative pathogenic bacteria E. coli, Serratia marcescens, as well as the Gram-positive pathogenic bacteria Listeria innocua and S. carnosus $[143,144]$. The peptide VLNENLLR (also known as caseicin B) inhibited the growth of pathogenic bacteria E. coli and Escherichia sakazakii at a concentration of $0.22 \mathrm{mmol} / \mathrm{L}$.

The $\beta$-casein-derived anti-microbial peptides YQEPVLGPVRGPFPI and YQEPVLGPVRGPFPIIV as well as isracidin have been found intact in the GI tract of mini-pig and calf suggesting a possible in vivo role for these bioactive peptides [145,146]. Indeed, Boutrou et al. [147] found that the $\beta$-casein-derived peptides VLPVPQK and EMPFPK were released in the human jejunal effluent during GI digestion of milk proteins.

\subsection{Anti-diabetic Peptides Identified in Commercial Fermented Dairy Products}

As reported by the World Health Organization (WHO), about the $90 \%$ of diabetes cases are ascribed to T2D and, globally, about 15 million people have T2D, a perspective that could double by 2025 [148-150].

Actual pharmacologic treatments for T2D focus on increasing insulin availability, improving sensitivity to insulin, delaying the absorption of glucose in the GI tract, or stimulating glucose excretion by urines. Dipeptidyl peptidase IV (DPP-IV) has emerged as a new target for the T2D treatment. DPP-IV is a serine endopeptidase located in the GI tract, kidneys, and endothelial layer of the vascular system. It is involved in the regulation of several physiological processes, such as blood glucose homeostasis [151]. DPP-IV is accountable for the quick degradation and inactivation of incretins such as glucagon-like peptide 1 (GLP-1) and glucose-dependent insulinotropic polypeptide (GIP) [152]. The incretin system plays a crucial role in the release of insulin from pancreatic $\beta$-cells, in response to high concentrations of blood glucose [150]. DPP-IV inhibitors extend the GLP-1 availability and 
improve glucose tolerance in diabetic patients by enhancing the GLP-1 activities [153,154]. Actually, natural peptides and food protein hydrolysates, which could act as potential inhibitors of DPP-IV attracted great interest of the scientific community. Specific peptide sequences, displaying an N-terminal $\mathrm{W}$ and/or $\mathrm{P}$ at the second position, demonstrated high effectiveness in inhibiting DPP-IV activity. Animal studies performed with food protein hydrolysates demonstrated that an assayed in vitro DPP-IV inhibitory effect is usually correlated to the antidiabetic effects in vivo. Their outcomes also reported that milk proteins and dairy products are especially rich in DPP-IV inhibitory peptides $[155,156]$. Uenishi et al. [157] identified 46 peptides derived from $\beta-, \alpha S 1-$, and $\alpha \mathrm{S} 2$-casein in commercial gouda-type cheese (Table 4 ).

Table 4. Peptides with in vitro dipeptidyl-peptidase-IV (DPP-IV) inhibitory activity identified in commercial fermented dairy products ${ }^{1}$.

\begin{tabular}{ccccc}
\hline Peptide & Fragment & Source & $\begin{array}{c}\text { IC }_{50} \\
\mu \text { mol/L }\end{array}$ & References \\
\hline WL & $\alpha$-lactalbumin $\mathrm{f}(104-105)$, & Yogurt & 44 & {$[55]$} \\
LPQNIPPL & $\alpha$-lactalbumin $\mathrm{f}(118-119)$ & Cheese & 46 & {$[157]$} \\
LPQ & $\beta$-casein $\mathrm{f}(70-77)$ & Cheese & 82 & {$[55]$} \\
VPITPTL & $\alpha$-casein $\mathrm{f}(70-72)$ & Cheese & 110 & {$[157]$} \\
VPITPT & $\alpha$ s2-casein $\mathrm{f}(117-123)$ & Cheese & 130 & {$[157]$} \\
LPQNIPP & $\beta$-casein $\mathrm{f}(117-122)$ & Cheese & 160 & {$[157]$} \\
GPFPILV & $\beta$-casein caprine $\mathrm{f}(201-207)$ & Kefir & 163 & {$[69]$} \\
FPGPIPN & $\beta$-casein $\mathrm{f}(62-68)$ & Cheese & 260 & {$[157]$} \\
YP & Various fragments in $\beta$-casein, & Yogurt & 658 & {$[55]$} \\
YPFPGPIPN & $\alpha$ S1-casein, $\mathrm{K}$-casein & Cheese, kefir & 670 & {$[48,58,73,157,158]$} \\
PGPIHNS & $\beta$-casein $\mathrm{f}(60-68)$ & Cheese & 1000 & {$[157]$} \\
IPPLTQTPV & $\beta$-casein $\mathrm{f}(63-69)$ & Cheese & 1300 & {$[157]$} \\
PQNIPPL & $\beta$-casein $\mathrm{f}(74-82)$ & Cheese & 1500 & {$[157]$} \\
VPPFIQPE & $\beta$-casein $\mathrm{f}(84-91)$ & Cheese & 2500 & {$[157]$} \\
\hline
\end{tabular}

${ }^{1}$ Peptides are classified according to their inhibitory strength; $\mathrm{IC}_{50}$ is defined as the amount of peptides $(\mu \mathrm{mol} / \mathrm{L})$ that cause the $50 \%$ inhibition of the enzymatic activity.

About the half of these peptides had an X-P structure at their N-termini. Among these, 10 have been tested for their DPP-IV inhibitory effect: VPITPT, LPQNIPP, PQNIPPL, VPITPTL, FPGPIPN, PGPIHNS, IPPLTQTPV, VPPFIQPE, YPFPGPIPN, and LPQNIPPL. The inhibitory activity, expressed as $\mathrm{IC}_{50}$ value, of LPQNIPPL ( $\beta-\mathrm{CN}$ f70-77) displayed to be the highest recorded effect. These results suggested that LPQNIPPL was the major DPP-IV-inhibitory peptide in cheese ripened for 12 months and played a significant role in in the in vivo inhibition of DPP-IV. The IC ${ }_{50}$ of VPITPTL ( $\beta$-CN f84-91), VPITPT ( $\alpha$ s2-CN f117-122), LPQNIPP ( $\beta$-CN f70-76), and FPGPIPN ( $\beta$-CN f62-68) were 110, 130, 160 , and $260 \mu \mathrm{mol} / \mathrm{L}$, respectively. In contrast, although IPPLTQTPV ( $\beta-\mathrm{CN}$ f74-82) and VPPFIQPE ( $\beta$-CN f84-91) and PQNIPPL ( $\beta$-CN f71-77) have the X-P structure, their IC $_{50}$ values were higher than $1000 \mu \mathrm{mol} / \mathrm{L}$. YPFPGPIPN, identified in kefir and gouda-type cheese, displayed DPP-IV inhibitory activity but with high $\mathrm{IC}_{50}$ value $(670 \mu \mathrm{mol} / \mathrm{L})$. Interestingly, its presence at the intestinal level after consumption of milk and dairy products suggests a high resistance capacity to the GI conditions and a greater probability to be absorbed and detected at the systemic level, available for further in vivo activities $[48,58,59,157]$. Other shorter peptide motifs were detected in yogurt by Kunda et al. [54]. LPQ and WL were the peptides with the highest inhibitory effect on DPP-IV, with $\mathrm{IC}_{50}$ values of about 82 and $44 \mu \mathrm{mol} / \mathrm{L}$, respectively.

However, the supporting evidences of an in vivo effect of DPP-IV inhibitory peptides in the T2D treatment are very scarce. The study of dietary peptides-mediated DPP-IV inhibition in humans is still in an embryonic phase. Food protein hydrolysates with DPP-IV inhibitory properties were mainly investigated in vitro. Very few studies analyzed serum DPP-IV activity after food administration. 
Scarce results about the DPP-IV activity reduction as a consequence of the consumption of protein-rich food are obtained [159]. Moreover, clear indication about the bioavailability of food-derived peptides is limited [160]. Despite that, it is likely that DPP-IV inhibition may be a crucial mechanism in the reported in vivo antidiabetic effects of intact or hydrolyzed food-proteins.

\section{FDF as Source of BPs-Producing LAB}

\subsection{FDF Microbiota under the Lens of Metagenomics and Genomics}

The abundance and diversity of BPs in FDF result from microbiota inhabiting these ecosystems. The LAB population strongly modulates the content, as well as the spatial diversification and temporal distribution of BPs through a balance between consumption and production. The most common LAB responsible for conversion of milk into FDF includes a heterogeneous arena of Gram-positive non-sporulating species belonging to the genera Lactococcus, Lactobacillus, Streptococcus, Leuconostoc, and Enterococcus [161]. These species are ubiquitous in several niches and, due to their long safe history in food production, the majority of them received the generally recognized as safe (GRAS) status by U.S. Food and Drug Administration (FDA) (http://www.accessdata.fda.gov/scripts/fdcc/?set=GRASNotices) and the qualified presumption of safety (QPS) approval by EFSA. Thirty-six Lactobacillus species have currently gained the qualified presumption of safety (QPS) status from EFSA [162]. The microorganisms involved in initial steps of milk fermentation processes, termed as "dairy starters" or "primary starters" (SLAB), have the pivotal function to convert lactose into lactic acid, leading to a fast lowering of $\mathrm{pH}$ and redox potential [163]. In cheese-making, SLAB also contribute to flavor development through lactose and citrate metabolism, lipolysis, and proteolysis with the subsequent catabolism of amino acids [164]. Natural or commercial starters are often limited to a few homofermentative LAB species. The mesophilic SLAB group comprises Lactococcus lactis ssp. lactis and Lactococcus lactis subsp. cremoris, but undefined natural starters can also contain strains of Leuconostoc spp. for the ability to ferment citrate [165]. The thermophilic SLAB, including L. helveticus, Streptococcus thermophilus, and L. delbrueckii subsp. bulgaricus, are most frequently encountered in natural starters for semi-hard and hard cheese-making. As an exception, kefir grains are complex consortia of yeasts (e.g., Saccharomyces, Candida, Kluyveromyces, Debaryomyces, and Torulaspora) and bacteria (e.g., Lactobacillus, Lactococcus, Leuconostoc, and Streptococcus) embedded in a polysaccharide matrix, used as a starter to produce a naturally carbonated, slightly acidic fermented dairy product [166].

Apart from yogurt that contains the protosymbiotic species St. thermophilus and L. delbrueckii subsp. bulgaricus, the microbiota of FDFs are often complex bacterial consortia with different species and strains, which drive the development of regional product qualities, as reviewed by Macori and Cotter [167]. In the case of cheese manufacturing, SLAB usually decrease by autolysis after curd acidification, whereas sub-dominant adventitious LAB, termed non-starter LAB (NSLAB), remain metabolically active and become dominant in the ecosystem during cheese ripening. NSLAB are mainly mesophilic facultatively (L. casei, Lactobacillus paracasei, Lactobacillus plantarum/paraplantarum, Lactobacillus pentosus, L. rhamnosus, and Lactobacillus curvatus) or obligately (Lactobacillus brevis Lactobacillus fermentum, Lactobacillus buchneri, and Lactobacillus parabuchneri) heterofementative lactobacilli derived from raw milk or cheese manufacturing environment and are pivotal in determining cheese flavor and texture. In some cases, pediococci, such as Pediococcus acidilactici and Pediococcus pentosaceus, enterococci, such as Enterococcus durans, Enterococcus faecalis and Enterococcus faecium, and also leuconostocs can be found in NSLAB populations [140].

Recently, metagenomic approaches reveal how FDF, especially cheese, possess fermentation-associated microbial communities more complex than that expected by culture-dependent approaches [167-170]. These communities undergo substantial fluctuations in function of time, space (core vs. surface), and specific combination of abiotic factors (shaping, mixture, salting, and temperature) [171]. On the other hand, the availability of an increasing number of genomes from dairy and non-dairy isolates supports how considerable differences exist at inter- and intra-species level, 
resulting in highly different niche adaptability and functionalities. This growing body of knowledge makes it possible to identify or predict functional traits of FDF-associated LAB. Genome analysis showed that dairy lactobacilli retained more genes involved in sugar transportation, proteolysis, and amino acid transportation compared to gut lactobacilli, a signal of adaptation to milk environment [172].

\subsection{The Renaissance of Interest Towards Artisanal FDF}

The market of functional foods is continuously asking for diversification of the range of available products. To meet this need, there is a growing interest to identify new bio-functional strains. Genomics and metagenomics evidences support how dairy LAB are not only important for modifying technological and organoleptic properties of FDF, but also promising candidates for promoting human health. The great inter and intra-species diversity of microbial consortia in FDF makes these matrices interesting bio-reservoirs of novel probiotic candidates. Evidences have been accumulating that FDFs are dietary source of live organisms [37] and that the allochthonous bacteria from FDF can resist stressful GIT conditions [173]. Despite their transient occurrence in the GI tract, dairy LAB can nonetheless influence the resident microbiome and exert host-specific health benefits [14]. In addition to human GIT, potential probiotic candidates have been recently isolated from different kinds of fermented milks [172-176], cheeses [177-182], and kefir. Even if rigorous guidelines define when a single microbe or microbial consortia can be properly qualified as probiotic [183], these studies provided the basis for the development of new functional foods and defined a cohort of strains which will be in future employed as therapeutic adjuvants for in vivo studies. Recently, Sanders and coworkers [184] proposed the concept of "shared core benefits" to explain how probiotic benefits can result from mechanisms conserved within the same taxon, overcoming the idea of strain-specific probiotic effects. Thus, although the FDF microbes cannot be considered probiotic, many of them are evolutionarily highly related to probiotic organisms, and they often share the same molecular mechanisms responsible for health-promoting properties in probiotics [37].

Following a similar trend, FDFs and ripened cheeses, in particular, became relevant sources for LAB suitable to enrich PHMs in food products thanks to the bacterial fermentative activities [185]. Table 5 summarized the main works, which investigated the capability of LAB isolated from FDF to produce BPs in novel food matrices. 
Table 5. Main lactic acid bacteria (LAB) strains isolated from FDFs and exploited in developing novel dairy food enriched in BPs.

\begin{tabular}{|c|c|c|c|c|c|}
\hline Species & Strain & Food Source & Novel Dairy Product & BPs-mediated Activities & References \\
\hline \multirow[t]{12}{*}{ L. helveticus } & 130B4 & Mongolian camel milk & Fermented skim milk & ACE-i & [186] \\
\hline & s6-HTCH, s10-AVCH, s12-AVCH & Mexican Chiapas cheese & Fermented milk & ACE-i & [187] \\
\hline & CM $4{ }^{1}, \mathrm{CP}_{9} 90^{1}$ & Japanese sour milk & Fermented milk & ACE-i & [188] \\
\hline & CPN4 $4^{1}$ & Japanese sour milk & Yogurt & ACE-i & {$[60]$} \\
\hline & $\mathrm{H} 9^{1}$ & $\begin{array}{l}\text { Traditional Tibetan kurut } \\
\text { (fermented yak milk) }\end{array}$ & $\begin{array}{l}\text { Different kinds of fermented } \\
\text { milk, yogurt }\end{array}$ & ACE-i & [189] \\
\hline & 141, T105 & Polish dairy products & Fermented milk & $\begin{array}{l}\text { Antioxidative, opioid, stimulating, } \\
\text { hypotensive, immunomodulating, } \\
\text { antibacterial and antithrombotic }\end{array}$ & [190] \\
\hline & DPC4571 & Swiss Cheese whey & $\begin{array}{l}\text { Fermented milk; adjunct in } \\
\text { Cheddar cheese }\end{array}$ & ACE-i & [192] \\
\hline & MTCC5463 & Indian dairy product & $\begin{array}{l}\text { Honey- flavored fermented } \\
\text { milk }\end{array}$ & Antihypertensive & [193] \\
\hline & LBB BY 21 & Yogurt & Fermented milk & Antimicrobial & [194] \\
\hline & ND01 & Chinese naturally fermented milk & Gouda cheese & ACE-i & [195] \\
\hline & PR4 & Italian cheese & Fermented caseinate & ACE-i & [196] \\
\hline & M92 & Spontaneously acidified milk & Yogurt & ACE-i & [197] \\
\hline \multirow[t]{5}{*}{ L. casei } & IMAU20411 & Chinese Dairy food & Fermented milk & ACE-i & [158] \\
\hline & Zhang & Koumiss & Cheddar cheese & ACE-i & [198] \\
\hline & PRA205 & Parmigiano Reggiano cheese & Fermented skim milk, yogurt & ACE-i & {$[80]$} \\
\hline & ATCC393 & Dairy food & Fermented milk & ACE-i, antioxidant and anticancer & [200] \\
\hline & АТСС393 & Dairy food & $\begin{array}{l}\text { Yogurt with St. thermophilus } \\
\text { and L. bulgaricus }\end{array}$ & & [201] \\
\hline \multirow[t]{3}{*}{ L. paracasei } & in co-culture with Candida & Comté cheese & Whey drink & $\begin{array}{l}\text { ACE-i, reduction in } \alpha \text {-lactalbumin } \\
\text { and } \beta \text {-lactoglobulin }\end{array}$ & [202] \\
\hline & MTCC 5945 (NS4) & Fermented milk & Fermented camel milk & ACE-i & [203] \\
\hline & PTCC 1637 & Camel sour milk & Fermented camel milk & ACE-i and antioxidant & [204] \\
\hline \multirow[t]{6}{*}{ L. plantarum } & 55 & $\begin{array}{l}\text { Portuguese raw ewe milk } \\
\text { semisoft cheeses }\end{array}$ & Fermented cow skim milk & $\begin{array}{c}\text { anti-inflammatory, antihemolytic and } \\
\text { antioxidant }\end{array}$ & [205] \\
\hline & KX881772, KX881779 & Camel milk & Fermented cow camel milk & ACE-i, antiproliferation & [206] \\
\hline & KX881772, KX881780 & Camel milk & Low-fat akawi cheese & ACE-i, antioxidant & [207] \\
\hline & 69 & Mongolian fermented cow milk & Fermented goat milk & ACE-i & [208] \\
\hline & LMG18024 & Buffalo milk & Fermented skim milk & ACE-i & [209] \\
\hline & BGPV2-45a, BGBUK 2-5, BGGA-8 & Homemade cheese & Fermented skim milk & ACE-i & [209] \\
\hline
\end{tabular}


Table 5. Cont.

\begin{tabular}{|c|c|c|c|c|c|}
\hline Species & Strain & Food Source & Novel Dairy Product & BPs-mediated Activities & References \\
\hline \multirow{4}{*}{$\begin{array}{c}\text { L. delbrueckii } \\
\text { subsp. bulgaricus }\end{array}$} & SS1 & Dairy product & Fermented milk & ACE-i & [210] \\
\hline & ACA-DC 87 & Greek sheep milk yogurt & Greek yogurt and feta cheese & ACE-i & [211] \\
\hline & b38 & Yogurt & Fermented milk & Antimicrobial & [194] \\
\hline & CRL 581 & Argentinian hard cheese & Fermented milk & ACE-i, anti-inflammatory & [212] \\
\hline \multirow{4}{*}{$\begin{array}{l}\text { Lc. lactis subsp. } \\
\text { lactis }\end{array}$} & NRRL B-50571, NRRL B-50572 & Cheese & Fermented cow milk & ACE-i & [213] \\
\hline & Q1, Q5 & Chihuahua cheese & Fermented milk & ACE-i & [214] \\
\hline & ESI197, M21, P21 & Manchego cheese & Manchego cheese & ACE-i & [215] \\
\hline & KX881782 & Camel milk & Fermented camel milk & ACE-i, antiproliferation & [206] \\
\hline $\begin{array}{l}\text { Lc. lactis subsp. } \\
\text { cremoris }\end{array}$ & FT4 & Dairy product & Fermented milk & ACE-i & [210] \\
\hline Leu. lactis & PTCC1899 & $\begin{array}{l}\text { Traditional fermented camel milk } \\
\text { (Chal) }\end{array}$ & Fermented milk & ACE-i, antioxidant & {$[176,216]$} \\
\hline \multirow[t]{5}{*}{ St. thermophilus } & ACA-DC 835 & Greek Cow milk yogurt & Greek yogurt and feta cheese & ACE-i & [211] \\
\hline & $\begin{array}{l}\text { LMD-9, PB302, PB385, CNRZ404, } \\
\text { ATE19PB8, Y4, HAD8a, CNRZ1066 }\end{array}$ & Yogurt & Fermented cow milk & $\begin{array}{l}\text { ACE-i, immunomodulating and } \\
\text { antimicrobial }\end{array}$ & [217] \\
\hline & CNRZ445 & Cheese & Fermented cow milk & ACE-i & [217] \\
\hline & ATCC19258 & Pasteurized milk & Fermented cow milk & ACE-i & [217] \\
\hline & $\begin{array}{l}\text { in co-culture with L. delbrueckii } \\
\text { subsp. bulgaricus }\end{array}$ & Yogurt & $\begin{array}{l}\text { milk-juice beverage with } \\
\text { fermented sheep milk and } \\
\text { strawberries }\end{array}$ & ACE-i & [218] \\
\hline \multirow[t]{2}{*}{ L. acidophilus } & L10 & Dairy food & Fermented milk & ACE-i & [219] \\
\hline & $\begin{array}{l}\text { NCDC-15 in co-culture with St. } \\
\text { thermophilus NCDC167 }\end{array}$ & Lassi & Fermented buffalo milk & $\begin{array}{l}\text { ACE-i, immunomodulatory, } \\
\text { antioxidant, opioid and } \\
\text { cytomodulatory }\end{array}$ & [220] \\
\hline \multirow[t]{2}{*}{ E. faecalis ${ }^{2}$} & СECT 5727, CECT 5728, CECT 5826, & Raw milk & Fermented skim milk & ACE-i & [221] \\
\hline & 43 & Brazilian artisanal ripened cheese & Fermented cow milk & $\mathrm{nr}$ & [222] \\
\hline
\end{tabular}


Table 5. Cont.

\begin{tabular}{|c|c|c|c|c|c|}
\hline Species & Strain & Food Source & Novel Dairy Product & BPs-mediated Activities & References \\
\hline \multirow[t]{2}{*}{ Kefir grains } & Lactobacilli and yeast consortium & - & Fermented cow milk & $\begin{array}{l}\text { antihypertensive, antimicrobial, } \\
\text { immunomodulatory, opioid and } \\
\text { anti-oxidative }\end{array}$ & [70] \\
\hline & Lactobacilli and yeast consortium & - & Kefir & ACE-i, antimicrobial & [223] \\
\hline L. reuteri & KX881777 & Camel milk & Fermented cow camel milk & ACE-i, antiproliferation & [206] \\
\hline P. acidilactici & 90 & Brazilian artisanal ripened cheese & Fermented cow milk & $\mathrm{nr}$ & [222] \\
\hline $\begin{array}{l}\text { Undefined LAB } \\
\text { species }\end{array}$ & s6-HTCH, s10-AVCH, s12-AVCH & Chiapas cream cheese & Fermented milk & ACE-i, antioxidant & [187] \\
\hline W. viridescens & 111 & Brazilian artisanal ripened cheese & Fermented cow milk & $\mathrm{nr}$ & [222] \\
\hline
\end{tabular}

${ }^{1}$ Calpis Food Industry Co. Ltd. (Tokyo, Japan) selected cultures; ${ }^{2}$ Ent. faecalis is not recommended for the QPS list (EFSA 2016). 
The majority of these works employed a so-called "reverse food engineering" strategy, which entailed the following three steps: (i) The isolation of LAB from traditional FDFs; (ii) the screening of LAB for the ability to release BPs; and (iii) the exploitation of the best BPs producer strains for innovation in dairy food fermentation (Figure 2).

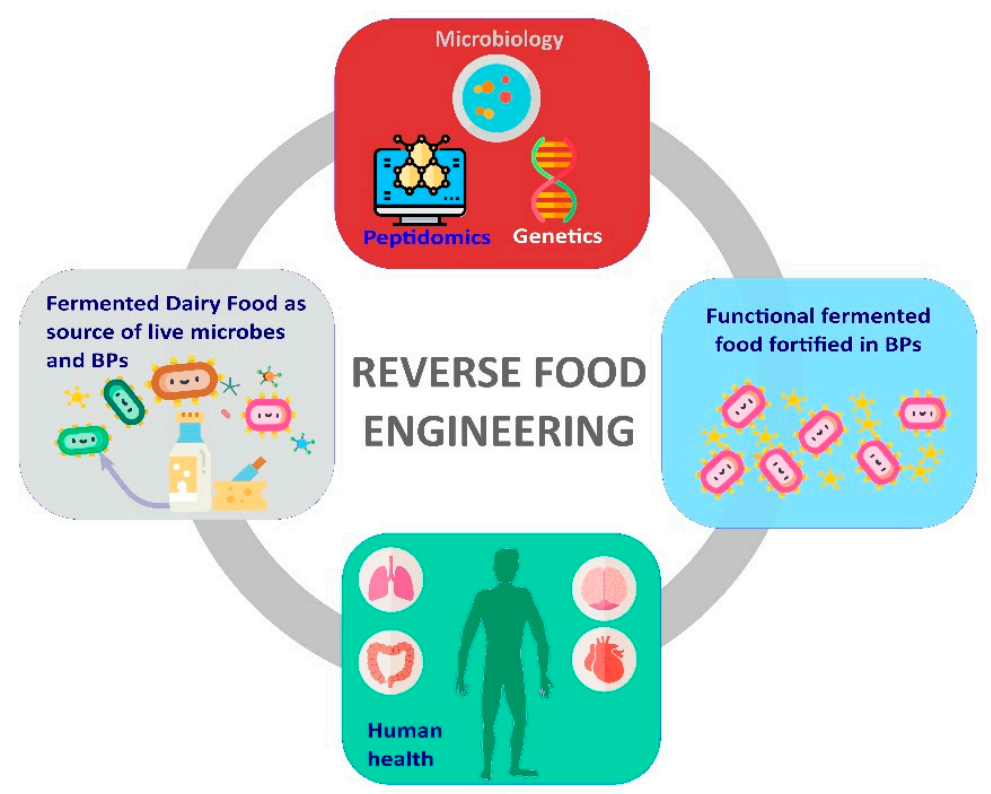

Figure 2. Overview of reverse food engineering approach. Reverse food engineering exploits fermented dairy foods (FDFs) as bio-reservoirs of microbes producing BPs and pro-health molecules and performs multidisciplinary analysis to improve content of BPS and healthy microbes in hyperfood.

L. helveticus exploited in hypotensive drinks such as Evolus (Valio Ltd., Valio, Finland) or sour milk like Calpis (Calpis Food Industry Co. Ltd., Tokyo, Japan) were isolated for spontaneous fermented milk or whey [188,224]. L. helveticus strains isolated from Mongolian fermented milks showed different BPs releasing abilities than L. helveticus strains from Western countries [225]. Brazilian cheeses, such as Manchego and Coalho cheeses [215], were found to be source of highly proteolytic LAB suitable to produce drinkable milk fortified in BPs. Similarly, Rutella et al. [80] successfully used BPs-producer NSLAB L. casei and L. rhamnosus from Parmigiano Reggiano ripened cheese to develop a yogurt enriched in ACE-i VPP and IPP.

\section{LAB Proteolytic System}

LAB have a complicated proteolytic apparatus, which is able to hydrolyze milk proteins resulting in the release of oligopeptides and then free amino acids. The most-studied proteolytic system was from Lc. lactis and includes three main constituents: a cell-envelope proteinase (CEP), transport systems for short peptides and amino acids, and a multitude of intracellular peptidases. Milk proteins are initially hydrolyzed to oligopeptides by CEP. Afterwards, the released peptides are transported inside the cells by specific transporters including oligopeptide transporters (Opp) and di-tripeptide transporters (Dpp, DtpP, and DtpT). Finally, peptidases convert these peptides into free amino acids, which are essential for the growth of LAB [215] (Figure 3A). 


\section{A}

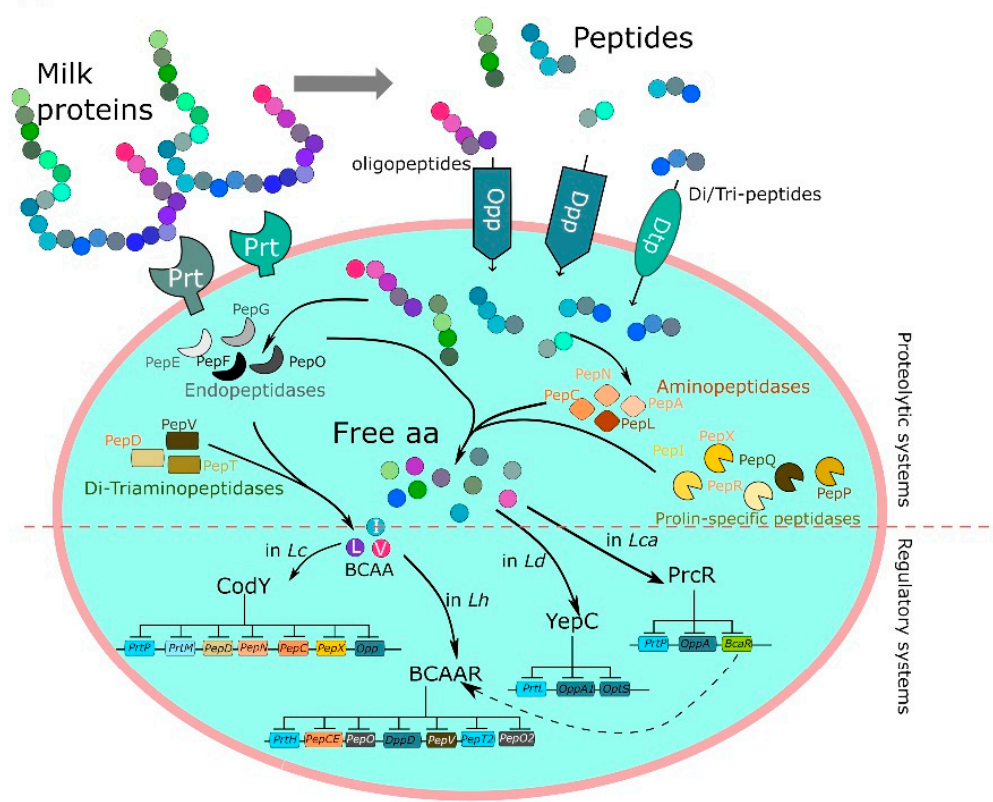

B

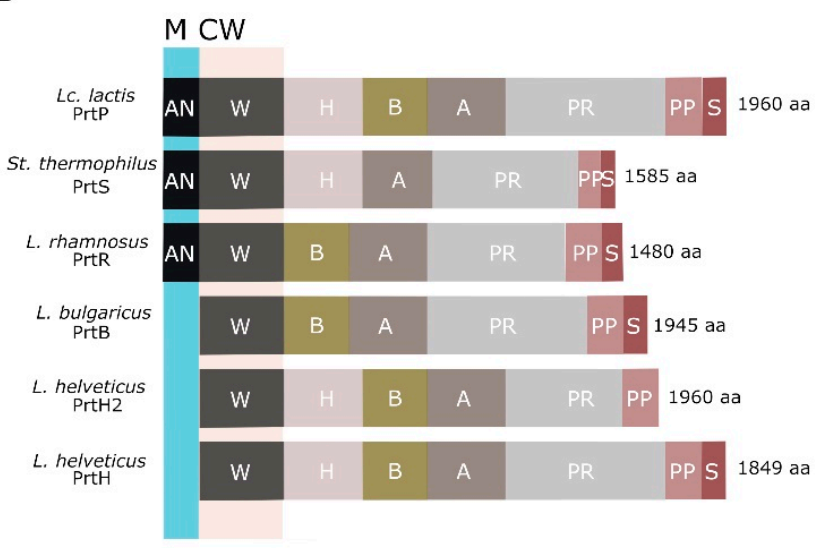

Figure 3. Comparative analysis of proteolytic systems in Lactococcus lactis and Lactobacillus spp. (A) Main effectors of proteolytic machinery and regulatory systems. (B) Multi-domain structure of prt proteinases isolated from Lactococcus lactis, Streptococcus thermophilus, and Lactobacillus spp. Abbreviations: BCAA, branched chain amino acids; Lc, Lactococcus lactis; Lb, Lactobacillus bulgaricus; M, membrane; CW, cellular wall; S, signal; PP, pro-domain; PR, proteolytic domain; A, A domain; $\mathrm{B}$, B domain; H, helix domain; $\mathrm{W}$, cell wall domain; $\mathrm{AN}$, anchoring domain. I domain was omitted for brevity.

Several evidences support that the lactococci and lactobacilli proteolytic systems are comparable in their components and modes of action in terms of converting milk proteins (primarily caseins) into oligopeptides and free amino acids. The most proteolytic species L. helveticus is one of the most nutritionally fastidious LAB, needing 14 exogenous amino acids [226]. This auxotrophy is counterbalanced by a potent proteolytic system, which fulfils the amino acid requirements of the L. helveticus cell [227]. Comparative genome analyses support that proteolytic enzymes are highly variable at inter and intra-species level, mainly for CEP-encoding genes, determining a huge variability in BPs release among different LAB strains. Therefore, the proteolytic activity of a given strain and the resulting BP profiles in food matrix finally depend on its CEP and peptidase patterns, on gene variations, and on the environmental conditions, which modulate proteolytic gene expression [228]. 


\subsection{Proteases}

CEPs are serine proteases belonging to the family of subtilisine, which catalyze the breakdown of caseins into oligopeptides. Based on the substrate specificity, CEPs were classified in three types: PI-type CEPs primarily hydrolyze $\beta$-casein; PIII-type CEPs are able to degrade all caseins, including $\alpha$ s1-, K-, and $\beta$-casein; PI/PII-type CEPs hydrolyze both $\beta$-casein and, to a lesser extent, $\alpha$ s1-casein [229]. Generally, LAB synthesize CEPs as preproteins of 2000 residues and, in their final arrangement, they include seven functional domains (from $\mathrm{N}$ to C-terminus): S, PP, PR, A, B, H, and W. Among these, $\mathrm{PP}$ is the pre-pro domain, which includes a typical signal sequence required for secretion, while PR identified the catalytic protease domain with a small inserted (I) domain, which can modify the prt-specificity. The A domain has unknown function, while the B domain probably plays a stabilizing role; the $\mathrm{H}$ domain is a helical spacer, whereas the $\mathrm{W}$ domain is a hydrophilic cell wall spacer or attachment domain [230]. Three distinct anchoring mechanisms were noted: A SLAP domain (S-layer anchoring domain), particularly present in the L. delbrueckii sub-clade, is responsible for the non-covalent interactions; a LPXTG motif involved in the covalent linkage to peptidoglycan; and a LPXTG motif-derivative. In some cases, like in L. helveticus, the typical CEP anchoring domain was not found at C-terminus and the sequences ended just before the typical start of the anchoring domain motif. Based on the anchoring system and the possibilities of various domain combinations, different CEPs were characterized in different LAB species, including PrtP from Lc. lactis, L. casei and L. paracasei, PrtH from L. helveticus, PrtR from L. rhamnosus, PrtS from S. thermophilus, and PrtB by L. delbrueckii subsp. bulgaricus, as reviewed by Liu et al. [231]. The main features of most relevant CEPs in LAB species are depicted in Figure 3B.

More recently, comparison of 213 genomes from Lactobacillus species revealed a more extensive diversity in CEP characteristics, with a total of 60 CEPs identified [232]. Most LAB possess only one type of CEP, while L. helveticus strains have at least two different prt paralogs, namely PrtH and PrtH2 [233]. In a survey of prt genes in different L. helveticus strains, Genay et al. [234] revealed that PrtH2 is almost always present. In some L. helveticus strains, like CNRZ32, prtH3, and prtH4 paralogs were also present [235]. PrtH1, PrtH2, PrtH3, and PrtH4 were expressed in a strain-dependent manner by L. helveticus [226]. In addition, L. helveticus, as other LAB species, requires a maturation proteinase named PrtM for the activation of CEP. In L. helveticus strain CNRZ32 two PrtMs (PrtM1 and PrtM2) have been identified [236]. Further studies [234,235,237] stated that PrtM is required for the activation of PrtH and PrtM2 and plays an important function in the activation of further L. helveticus CEP paralogs.

\subsection{Transport System and Peptidases}

Peptides liberated by the hydrolytic action of CEPs are then imported by several transport systems within the cells, where they can be further cleaved by intracellular peptidases, releasing amino acids. Different transport apparatuses are implicated in the internalization of peptides in LAB: The oligopeptide permease system (Opp), the dipeptide permease system (Dpp), and transporter of di/tripeptides (DtpT).

The Opp system falls into the superfamily of ATP-binding cassette (ABC) and is able to transport oligopeptides from 4 up to 35 amino acids [238-240]. Biochemical and genetic characterization of the Opp system in Lc. lactis revealed that it is composed by five different proteins: The protein OppA that is responsible for the oligopeptides binding, the integral membrane OppB and OppC proteins, and the nucleotide-binding OppD and OppF proteins [238,240]. The genes encoding for the Opp system domains are located upstream the pepO gene, encoding for the endopeptidase PepO [237]. The system was also genetically characterized in L. delbrueckii subsp. bulgaricus, where an extra homolog gene oppA2 is present [241]. The Opp system of other LAB was not widely investigated, but Liu et al. [231] found the genes for the Opp system in several strains of L. acidophilus, L. brevis, L. casei, L. rhamnosus, L. johnsonii, L. gasseri, and L. helveticus. Most of the sequenced strains possessed more copies of the oligopeptides-binding protein OppA. Strains belonging to the L. acidophilus group, such as L. acidophilus, 
L. johnsonii, and L. gasseri, possessed the highest number of OppA genes [231]. However, at present, it is not clear whether all these paralogs are functional.

The DtpT transport system belongs to the family of the PTR (proton motive force-driven peptide transport system) [242]. DtpT, firstly identified in Lc. lactis, is a transmembrane protein of 12 residues with the C-and $\mathrm{N}$ - terminal facing the cytoplasm and $D \operatorname{tp} T$ gene positioned after the $p e p N$ gene, which encode the aminopeptidase PepN. This system shows a higher affinity for hydrophilic and charged di- and tripeptides [242]. Other LAB, such as L. helveticus, possess a DtpT system with similar specificity as that found in L. lactis [243]. Finally, Liu et al. [231] found the DtpT gene in several LAB strains including some species of interest for dairy fermentation such as L. acidophilus, L. brevis, L. casei, and L. rhamnosus.

Focaud et al. [244] firstly identified in Lc. lactis a third transport system (Dpp) belonging to the ABC superfamily and with a preference for di- and tripeptides that contained hydrophobic branched-chain amino acids. The Dpp system is organized as the Opp system with the subunit DppA, which is responsible, in analogy with OppA, for the binding of di- and tripeptides [245]. In both the systems, the peptide-binding proteins (DppA and OppA) are fixed to the membrane thorough a modified cysteine residue at the $\mathrm{N}$-terminal and deliver peptides to their cognate membrane complexes [246]. The Dpp system appeared to be widely distributed among the genomes of Lactobacillus species with the DppA gene being often present in multiple copies [231].

Following the internalization, numerous cytoplasmic peptidases cooperate to degrade the casein-derived peptides with different and partly overlapping specificities [236,247]. The LAB intracellular peptidase can be divided in four groups depending on their specificity: Aminopeptidases (PepN, PepC, PepA, PepM, PepP, and PepX), endopeptidases (PepE, PepG, PepF, and PepO), and di/tri-peptidases (PepI, PepL, PepQ, PepR, PepD, PepV, and PepT) (Figure 3A).

Endopeptidases are probably the first enzymes involved in the processing of peptides transported inside the cells. PepG, PepE, and its paralog PepE2 are cysteine-peptidases, whereas PepF and PepO have been classified as metallopeptidases [248-252]. At least in L. helveticus, two paralogs of PepO, named PepO2 and PepO3, with different specificity have been characterized [250,253]. $\mathrm{LAB}$ endopeptidases are able to hydrolyze, with different specificity, oligopeptides from 5 to 35 amino acid residues but they were not able to act on intact caseins [236,247].

Other peptidases able to act on oligopeptides are the aminopeptidases PepN, PepC, PepA, PepM, and PepP that were characterized in diverse dairy LAB species, such as L. casei, L. helveticus, L. bulgaricus, and Lc. lactis $[236,247,254-257]$. The metallopeptidases PepA and PepM have very defined substrate specificities and are able to remove the $\mathrm{N}$-terminal amino acids $\mathrm{N} / \mathrm{E}$ and $\mathrm{M}$, respectively. On the contrary, the metallopeptidase PepN and the cysteine-peptidase PepC have very broad substrate specificity $[236,247]$. The metallopeptidase PepP is active on oligopeptides from three to nine amino acids length and is characterized for their ability to hydrolyze the N-terminal amino acid when the residue in second position is $P[258,259]$. An additional aminopeptidase active on oligopeptides of three to seven amino acids is PepX. PepX activity has been detected in several LAB strains isolated from FDFs such as L. rhamnosus, L. casei, L. helveticus, L. delbrueckii subsp. bulgaricus, and Lc. lactis [236,247,260,261]. PepX is a prolyl dipeptidyl aminopeptidase able to liberate X-P di peptides from the N-terminus of an oligopeptides $[236,247]$.

Di- and tripeptides generated by the action of endopeptidases and aminopeptidases are further cleaved in the individual amino acids by the action of di/tri-peptidases. The tri-peptidase PepT and the di-peptidases PepD and PepV are characterized for a broad range of substrate specificity with preference for peptides containing hydrophobic amino acids $[236,247,262,263]$. They have been characterized in several LAB strains of paramount importance in dairy fermentation such as L. casei, L. helveticus, L. delbrueckii subsp. bulgaricus, L. sake, and Lc. lactis $[236,247,262,263]$. With the exception of PepL, which releases the amino acid $\mathrm{L}$ at the N-terminus from di- and tripeptides, the others characterized di/tri-peptidases (PepI, PepQ, and PepR) are classified as proline peptidases, each with its own specificities [264-266]. PepI and PepR are proline aminopeptidase, which release the amino acid 
P from di- and tripeptides and dipeptides, respectively. Instead, PepQ is a proline carboxypeptidase, which releases the residue $\mathrm{P}$ from the $\mathrm{C}$-terminus of a dipeptide. These peptidases are widely distributed among LAB strains and have been characterized in L. rhamnosus, L. casei, L. helveticus, L. delbrueckii subsp. bulgaricus, and Lc. lactis.

Comparative genomics studies support that the cytoplasmic peptidases PepN, PepC, and PepX were commonly found among Lactobacillus, encompassing species of importance in dairy fermentation [231,267]. Genes encoding for some peptidases, such as PepC, PepE, PepD, and PepO, were detected as multiple copies in LAB dairy strains, suggesting that these genes could be involved in adaption to habitats rich in proteins and peptides [231,267].

The heterogeneity in the presence of peptidases is also observed at intra-species level, where co-specific strains diverge for the type and number of transport system and peptidases. Comparative analysis of four L. delbrueckii subsp. bulgaricus genomes (ATCC 11842, BAA-365, 2038, and ND02) showed that the highest number genes encoding proteases, peptidases, and different transport systems were found in strain ND02. With regard to the strain 2038, two cell surface peptidases PepD4 and En1A were found as whole genes, suggesting that this strain is characterized by a stronger proteolytic ability, potentially producing higher amounts of free amino acids than the other strains [231]. All four sequenced strains are equipped with two complete Opp transport apparatuses, but the number and arrangement of the substrate binding protein OppA was different. The industrial strain 2038 was characterized by the highest number of genes encoding the OppA protein [231].

Intracellular peptidases have an important role in cheese maturation. For example, PepX and PepN are partially accountable for the release of volatile aroma-active molecules from milk proteins during cheese ripening [268]. Some other peptidases, such as PepE, PepN, and PepO (and its paralogs $\mathrm{PepO} 2$ and $\mathrm{PepO} 3$ ), have been found to hydrolyze the peptide corresponding to the $\beta$-casein fragment 193-209, which confers the major bitter taste defect in Gouda and Cheddar cheeses $[250,269,270]$.

Recently, the contribution of L. helveticus intracellular peptidases to the release of the antihypertensive lactotripeptides IPP and VPP, from the peptides released by the action of PrtP on $\beta$-casein, has been demonstrated. A key enzyme for the processing of VPP and IPP, with high homology to the endopeptidase PepO, has been identified and characterized in L. helveticus CM4 strain [271]. This endopeptidase can catalyze the hydrolysis of the C-terminal amino acid residues form the peptides VPPFL and IPPLT, releasing VPP and IPP, respectively. Some other aminopeptidases such as PepC and PepX may be involved in the N-terminal processing of VPP- and IPP-containing peptides [272,273]. However, to obtain more detailed information on the processing involved in VPP and IPP production, it should be of paramount importance to study the release of the lactotripeptides or precursors in Lactobacillus strains expressing or disrupting each specific peptidase gene.

\subsection{Regulation of Proteolytic Systems}

Proteolytic genes, especially prt ones, are generally repressed in cells growing in nitrogen sources-enriched medium. Regulatory mechanisms that modulate the proteolytic machinery have been well studied in Lc. lactis, where the GTP-binding protein CodY is implicated in the repression of various genes (prtP/prtM, opp-pepO1, pepD, pepN, pepC, and pepX) of the proteolytic system in consequence of the availability of branched-chain amino acids (BCAA) [274]. In Lc. lactis CodY also regulates aminotransferases AraT and $\mathrm{BcaT}$, which play a pivotal role in regulating the intracellular pool of amino acids [275].

In lactobacilli, no CodY-like proteins were found until now, such that the knowledge about the regulation of the genes encoding proteinases and peptidases remained scarce. Only recently, three works partially elucidated the regulatory mechanisms of proteolysis in L. helveticus, L. casei, and L. delbrueckii subsp. lactis. In L. helveticus CM4, transcriptional negative regulation of the proteolytic apparatus in response to amino acids is mediated by a BCAA-responsive transcriptional regulator (BCARR), which reduces the production of antihypertensive peptides by CM4 when amino acids are available in the surrounding medium [276]. The DNA-binding proteins YebC and PrcR are responsible 
for extracellular peptide-dependent repression of the genes of the proteolytic system in L. delbrueckii subsp. lactis CRL 581 and L. casei BL23, respectively [228,277] (Figure 3B). Differently from L. helveticus and Lc. lactis, both these regulators are unresponsive to BCAA. Interestingly, PrcR was found to negatively regulate the BcaR gene encoding for a protein orthologous to BCARR, suggesting that PrcR could be the master regulator of a regulatory network responsive to amino acid starvation more complex than that found in in L. helveticus [228]

\section{Conclusions}

Collective data from FDF peptidomics and LAB genomics and metagenomics represent important steps to realize the knowledge-based development of food enriched in BPs. The insights into the patterns of BPs in FDF and the microbiota responsible for their release enable the exploitation of FDF as resource for isolating novel potential BP producer strains. At the same time, knowledge on genes involved in BP release phenotype can drive and shorten the screening of the most interesting proteolytic candidates, opening the possibilities for development of products with diverse or enhanced BP patterns and broadens the overall portfolio offered to the final customer. This approach, here referred to as reverse food engineering (Figure 2), will allow the improvement of knowledge on the strict but still poorly explored link between diet and health.

Supplementary Materials: Supplementary materials can be found at http://www.mdpi.com/2311-5637/5/4/96/s1. Author Contributions: Conceptualization, L.S.; methodology, D.T., S.M. and L.S.; writing-review and editing, D.T., S.M. and L.S.

Funding: This research was funded by the 2017 grant provided by Consorzio del Formaggio Parmigiano Reggiano.

Conflicts of Interest: The authors declare no conflicts of interest. The funders had no role in the design of the study; in the collection, analyses, or interpretation of data; in the writing of the manuscript, or in the decision to publish the review.

\section{References}

1. World Health Organization. WHO Action Plan for Implementation of the European Strategy for the Prevention and Control of Noncommunicable Diseases, 2012-2016. World Health Organization, Regional Office for Europe, 2012. Available online: http://www.euro.who.int/_data/assets/pdf_file/0019/170155/e96638.pdf (accessed on 1 September 2019).

2. Carruba, G.; Cocciadiferro, L.; Di Cristina, A.; Granata, O.M.; Dolcemascolo, C.; Campisi, I.; Zarcone, M.; Cinquegrani, M.; Traina, A. Nutrition, aging and cancer: Lessons from dietary intervention studies. Immun. Ageing 2016, 13, 13. [CrossRef]

3. Tilman, D.; Clark, M. Global diets link environmental sustainability and human health. Nature 2014, 515, 518-522. [CrossRef]

4. Martirosyan, D.M.; Singh, J. A new definition of functional food by FFC: What makes a new definition unique? Funct. Food Health Dis. 2015, 5, 209-223.

5. Tuomilehto, J.; Tiss, A.; Tsang, C.; Khadir, A.; Bahorun, T.; Alkhatib, A.; Arefanian, H.; Barake, R. Functional foods and lifestyle approaches for diabetes prevention and management. Nutrients 2017, 9, 1310.

6. Battino, M.; Forbes-Hernández, T.Y.; Gasparrini, M.; Afrin, S.; Cianciosi, D.; Zhang, J.; Manna, P.P.; Reboredo-Rodríguez, P.; Varela Lopez, A.; Quiles, J.L.; et al. Relevance of functional foods in the Mediterranean diet: The role of olive oil, berries and honey in the prevention of cancer and cardiovascular diseases. Crit. Rev. Food Sci. Nutr. 2019, 59, 893-920. [CrossRef] [PubMed]

7. Veselkov, K.; Gonzalez, G.; Aljifri, S.; Galea, D.; Mirnezami, R.; Youssef, J.; Bronstein, M.; Laponogov, I. HyperFoods: Machine intelligent mapping of cancer-beating molecules in foods. Sci. Rep. 2019, 9, 9237. [CrossRef] [PubMed]

8. Cordain, L.; Eaton, S.B.; Sebastian, A.; Mann, N.; Lindeberg, S.; Watkins, B.A.; O'Keefe, J.H.; Brand-Miller, J. Origins and evolution of the Western diet: Health implications for the 21st century. Am. J. Clin. Nutr. 2005, 81, 341-354. [CrossRef] [PubMed] 
9. Douglas, G.L.; Klaenhammer, T.R. Genomic evolution of domesticated microorganisms. Annu. Rev. Food Sci. Technol. 2010, 1, 397-414. [CrossRef] [PubMed]

10. Campbell-Platt, G. Fermented foods-A world perspective. Food Res. Int. 1994, 27, 253-257. [CrossRef]

11. Metchnikoff, E. The Prolongation of Life; Putnam's Sons: New York, NY, USA; London, UK, 1908.

12. van Hylckama, V.J.E.; Veiga, P.; Zhang, C.; Derrien, M.; Zhao, L. Impact of microbial transformation of food on health-From fermented foods to fermentation in the gastro-intestinal tract. Curr. Opin. Biotechnol. 2011, 22, 211-219. [CrossRef]

13. Shiby, V.K.; Mishra, H.N. Fermented milks and milk products as functional foods-A Review. Crit. Rev. Food Sci. Nutr. 2013, 53, 482-496. [CrossRef] [PubMed]

14. Marco, M.L.; Heeney, D.; Binda, S.; Cifelli, C.J.; Cotter, P.D.; Foligné, B.; Gänzle, M.; Kort, R.; Pasin, G.; Pihlanto, A.; et al. Health benefits of fermented foods: Microbiota and beyond. Curr. Opin. Biotechnol. 2017, 44, 94-102. [CrossRef] [PubMed]

15. Mozaffarian, D. Changes in diet and lifestyle and long-term weight gain in women and men. N. Engl. J. Med. 2011, 364, 2392-2404. [CrossRef] [PubMed]

16. Keast, D.R.; Hill Gallant, K.M.; Albertson, A.M.; Gugger, C.K.; Holschuh, N.M. Associations between yogurt, dairy, calcium, and vitamin D intake and obesity among U.S. children aged 8-18 years: NHANES, 2005-2008. Nutrients 2015, 7, 1577-1593. [CrossRef] [PubMed]

17. Pothuraju, R.; Sharma, R.K.; Chagalamarri, J.; Kavadi, P.K.; Jangra, S. Influence of milk fermented with Lactobacillus rhamnosus NCDC 17 alone and in combination with herbal ingredients on diet induced adiposity and related gene expression in C57BL/6J mice. Food Funct. 2015, 6, 3576-3584. [CrossRef] [PubMed]

18. Panahi, S.; Tremblay, A. The potential role of yogurt in weight management and prevention of type 2 diabetes. J. Am. Coll. Nutr. 2016, 35, 717-731. [CrossRef]

19. Chen, G.C.; Szeto, I.M.Y.; Chen, L.H.; Han, S.F.; Li, Y.J.; van Hekezen, R.; Qin, L.Q. Dairy products consumption and metabolic syndrome in adults: Systematic review and meta-analysis of observational studies. Sci. Rep. 2015, 5, 14606. [CrossRef]

20. Capel, F.; Bongard, V.; Malpuech-Brugère, C.; Karoly, E.; Michelotti, G.A.; Rigaudière, J.P.; Jouve, C.; Ferrières, J.; Marmonier, C.; Sébédio, J.L. Metabolomics reveals plausible interactive effects between dairy product consumption and metabolic syndrome in humans. Clin. Nutr. 2019. [CrossRef]

21. Engberink, M.F.; Hendriksen, M.A.H.; Schouten, E.G.; van Rooij, F.J.; Hofman, A.; Witteman, J.C.; Geleijnse, J.M. Inverse association between dairy intake and hypertension: The Rotterdam study. Am. J. Clin. Nutr. 2009, 89, 1877-1883. [CrossRef]

22. Huang, W.Y.; Davidge, S.T.; Wu, J. Bioactive natural constituents from food sources-potential use in hypertension prevention and treatment. Crit. Rev. Food Sci. Nutr. 2013, 53, 615-630. [CrossRef]

23. Fekete, A.A.; Givens, D.I.; Lovegrove, J.A. Casein-derived lactotripeptides reduce systolic and diastolic blood pressure in a meta-analysis of randomised clinical trials. Nutrients 2015, 7, 659-681. [CrossRef] [PubMed]

24. Chen, M.; Sun, Q.; Giovannucci, E.; Mozaffarian, D.; Manson, J.E.; Willett, W.C.; Hu, F.B. Dairy consumption and risk of type 2 diabetes: 3 cohorts of US adults and an updated meta-analysis. BMC Med. 2014, 12, 215. [CrossRef] [PubMed]

25. Díaz-López, A.; Bulló, M.; Martínez-González, M.A.; Corella, D.; Estruch, R.; Fitó, M.; Gómez-Gracia, E.; Fiol, M.; García de la Corte, F.J.; Ros, E.; et al. Dairy product consumption and risk of type 2 diabetes in an elderly Spanish Mediterranean population at high cardiovascular risk. Eur. J. Nutr. 2016, 55, 349-360.

26. Barengolts, E.; Smith, E.D.; Reutrakul, S.; Tonucci, L.; Anothaisintawee, T. The effect of probiotic yogurt on glycemic control in type 2 diabetes or obesity: A meta-analysis of nine randomized controlled trials. Nutrients 2019, 11, E671. [CrossRef]

27. Cavero-Redondo, I.; Alvarez-Bueno, C.; Sotos-Prieto, M.; Gil, A.; Martinez-Vizcaino, V.; Ruiz, J.R. Milk and Dairy Product consumption and risk of mortality: An overview of systematic reviews and meta-analyses. Adv. Nutr. 2019, 10 (Suppl. 2), S97-S104. [CrossRef]

28. Thorning, T.K.; Bertram, H.C.; Bonjour, J.P.; de Groot, L.; Dupont, D.; Feeney, E.; Ipsen, R.; Lecerf, J.M.; Mackie, A.; McKinley, M.C.; et al. Whole dairy matrix or single nutrients in assessment of health effects: Current evidence and knowledge gaps. Am. J. Clin. Nutr. 2017, 105, 1033-1045. [CrossRef]

29. Lebeer, S.; Bron, P.A.; Marco, M.L.; Van Pijkeren, J.P.; O’Connell Motherway, M.; Hill, C.; Pot, B.; Roos, S.; Klaenhammer, T. Identification of probiotic effector molecules: Present state and future perspectives. Curr. Opin. Biotechnol. 2018, 49, 217-223. [CrossRef] 
30. Kleerebezem, M.; Binda, S.; Bron, P.A.; Gross, G.; Hill, C.; van Hylckama Vlieg, J.E.T.; Lebeer, S.; Satokari, R.; Ouwehand, A.C. Understanding mode of action can drive the translational pipeline towards more reliable health benefits for probiotics. Curr. Opin. Biotechnol. 2019, 56, 55-60. [CrossRef]

31. Bu, G.; Luo, Y.; Chen, F.; Liu, K.; Zhu, T. Milk processing as a tool to reduce cow's milk allergenicity: A mini-review. Dairy Sci. Technol. 2013, 93, 211-223. [CrossRef]

32. Gobbetti, M.; Minervini, F.; Rizzello, C.G. Bioactive peptides in dairy products. In Handbook of Food Products Manufacturing; Hui, Y.H., Ed.; John Wiley and Sons, Inc.: Hoboken, NJ, USA, 2007; pp. 489-517.

33. Gareau, M.G.; Sherman, P.M.; Walker, W.A. Probiotics and the gut microbiota in intestinal health and disease. Nat. Rev. Gastroenterol. Hepatol. 2010, 7, 503-514. [CrossRef]

34. Castro, J.M.; Tornadijo, M.E.; Fresno, J.M.; Sandoval, H. Biocheese: A food probiotic carrier. Biomed Res. Int. 2015, 2015, 723056. [CrossRef] [PubMed]

35. Şanlier, N.; GÖkcen, B.B.; Sezgİn, A.C. Health Benefits of Fermented Foods. Crit. Rev. Food Sci. Nutr. 2019, 59, 506-527. [CrossRef] [PubMed]

36. Marangoni, F.; Pellegrino, L.; Verduci, E.; Ghiselli, A.; Bernabei, R.; Calvani, R.; Cetin, I.; Giampietro, M.; Perticone, F.; Piretta, L.; et al. Cow's Milk Consumption and Health: A Health Professional's Guide. J. Am. Coll. Nutr. 2019, 38, 197-208. [CrossRef] [PubMed]

37. Rezac, S.; Kok, C.R.; Heermann, M.; Hutkins, R. Fermented foods as a dietary source of live organisms. Front. Microbiol. 2018, 9, 1785. [CrossRef] [PubMed]

38. Yahfoufi, N.; Mallet, J.F.; Graham, E.; Matar, C. Role of probiotics and prebiotics in immunomodulation. Curr. Opin. Food Sci. 2018, 20, 82-91. [CrossRef]

39. Korhonen, H.; Pihlanto, A. Bioactive peptides: Production and functionality. Int. Dairy J. 2006, 16, $945-960$. [CrossRef]

40. Cicero, A.F.G.; Fogacci, F.; Colletti, A. Potential role of bioactive peptides in prevention and treatment of chronic diseases: A narrative review. Br. J. Pharm. 2017, 174, 1378-1394. [CrossRef]

41. Vermeirssen, V.; Van, C.J.; Verstraete, W. Bioavailability of angiotensin I converting enzyme inhibitory peptides. Br. J. Nutr. 2004, 92, 357-366. [CrossRef]

42. Xu, Q.; Hong, H.; Wu, J.; Yan, X. Bioavailability of bioactive peptides derived from food proteins across the intestinal epithelial membrane: A review. Trends Food Sci. Technol. 2019, 86, 399-411. [CrossRef]

43. Udenigwe, C.C.; Fogliano, V. Food matrix interaction and bioavailability of bioactive peptides: Two faces of the same coin? J. Funct. Foods 2017, 35, 9-12. [CrossRef]

44. Caira, S.; Pinto, G.; Vitaglione, P.; Dal Piaz, F.; Ferranti, P.; Addeo, F. Identification of casein peptides in plasma of subjects after a cheese-enriched diet. Food Res. Int. 2016, 84, 108-112. [CrossRef]

45. Williams, B.; Mancia, G.; Spiering, W.; Agabiti Rosei, E.; Azizi, M.; Burnier, M.; Clement, D.L.; Coca, A.; de Simone, G.; Diminiczak, A.; et al. 2018 ESC/ESH Guidelines for the management of arterial hypertension. Eur. Heart J. 2018, 39, 3021-3104. [CrossRef] [PubMed]

46. Borghi, C.; Cicero, A.F.G. Nutraceuticals with clinically detectable blood pressure lowering effect: A review of available randomized clinical trials and their meta-analyses. Br. J. Clin. Pharm. 2017, 83, 163-171. [CrossRef] [PubMed]

47. Fekete, A.A.; Givens, D.I.; Lovegrove, J.A. The impact of milk proteins and peptides on blood pressure and function: A review of evidence from human intervention studies. Nutr. Res. Rev. 2013, 26, 177-190. [CrossRef] [PubMed]

48. Fitzgerald, R.J.; Murray, B.A. Bioactive peptides and lactic fermentations. Int. J. Dairy Technol. 2006, 59, 118-125. [CrossRef]

49. Acharya, K.R.; Sturrock, E.D.; Riordan, J.F.; Ehlers, M.R.W. ACE revisited a new target for structure-based drug design. Nat. Rev. 2013, 2, 891-902. [CrossRef]

50. Coates, D. The angiotensin converting enzyme (ACE). Int. J. Biochem. Cell. Biol. 2003, 35, 769-773. [CrossRef]

51. Cicero, A.F.G.; Gerocarni, B.; Laghi, L.; Borghi, C. Blood pressure lowering effect of lactotripeptides assumed as functional foods: A meta-analysis of current available clinical trials. J. Hum. Hypertens. 2011, 25, 425-436. [CrossRef]

52. Nakamura, Y.; Yamamoto, N.; Sakai, K.; Takano, T. Anti-hypertensive effect of sour milk and peptides isolated from it that are inhibitors to angiotensin I-converting enzyme. J. Dairy. Sci. 1995, 78, 1253-1257. [CrossRef] 
53. Basiricò, L.; Catalani, E.; Morera, P.; Cattaneo, S.; Stuknyte, M.; Bernabucci, U.; De Noni, I.; Nardone, A. Release of angiotensin converting enzyme-inhibitor peptides during in vitro gastrointestinal digestion of Parmigiano Reggiano PDO cheese and their absorption through an in vitro model of intestinal epithelium. J. Dairy Sci. 2015, 98, 7595-7601. [CrossRef]

54. Stuknyte, M.; Cattaneo, S.; Masotti, F.; De Noni, I. Occurrence and fate of ACE-inhibitor peptides in cheeses and in their digestates following in vitro static gastrointestinal digestion. Food Chem. 2015, 168, 27-33. [CrossRef] [PubMed]

55. Kunda, P.B.; Benavente, F.; Catalá-Clariana, S.; Giménez, E.; Barbosa, J.; Sanz-Nebot, V. Identification of bioactive peptides in a functional yogurt by micro liquid chromatography time-of-flight mass spectrometry assisted by retention time prediction. J. Chromatogr. A 2012, 1229, 121-128. [CrossRef] [PubMed]

56. Chanson-Rolle, A.; Aubin, F.; Braesco, V.; Hamasaki, T.; Kitakaze, M. Influence of the lactotripeptides Isoleucine-Proline-Proline and Valine-Proline-Proline on systolic blood pressure in Japanese subjects. PLoS ONE 2015, 10, e0142235. [CrossRef] [PubMed]

57. Cicero, A.F.G.; Aubin, F.; Braesco, V.; Borghi, C. Do the lactotripeptides Isoleucine-Proline-Proline andValine-Proline-Proline reduce systolic blood pressure in European subjects? Am. J. Hypertens. 2013, 26, 442-449. [CrossRef] [PubMed]

58. Sieber, R.; Bütikofer, U.; Egger, C.; Portmann, R.; Walther, B.; Wechsler, D. ACE-inhibitory activity and ACE-inhibiting peptides in different cheese varieties. Dairy Sci. Tech. 2010, 90, 47-73. [CrossRef]

59. Lu, Y.; Govindasamy-Lucey, S.; Lucey, J.A. Angiotensin-I-converting enzyme-inhibitory peptides in commercial Wisconsin Cheddar cheeses of different ages. J. Dairy Sci. 2016, 99, 41-52. [CrossRef] [PubMed]

60. Yamamoto, N.; Maeno, M.; Takano, T. Purification and characterization of an anti-hypertensive peptide from a yogurt-like product fermented by Lactobacillus helveticus CPN4. J. Dairy Sci. 1999, 82, 1388-1393. [CrossRef]

61. Maeno, M.; Yamamoto, N.; Takano, T. ldentification of an anti-hypertensive peptide from casein hydrolysate produced by a proteinase from Lactobacillus helveticus CP790. J. Dairy Sci. 1996, 79, 1316-1321. [CrossRef]

62. Miguel, M.; Recio, I.; Ramos, M.; Delgado, M.A.; Aleixandre, M.A. Antihypertensive effect of peptides obtained from Enterococcus faecalis-fermented milk in rats. J. Dairy Sci. 2006, 89, 3352-3359. [CrossRef]

63. Contreras, M.M.; Carrón, R.; Montero, M.J.; Ramos, M.; Recio, I. Novel casein-derived peptides with antihypertensive activity. Int. Dairy J. 2009, 19, 566-573. [CrossRef]

64. Contreras, M.M.; Sanchez, D.; Sevilla, M.A.; Recio, I.; Amigo, L. Resistance of casein-derived bioactive peptides to simulated gastrointestinal digestion. Int. Dairy J. 2013, 32, 71-78. [CrossRef]

65. Rival, S.G.; Boeriu, C.G.; Wichers, H.J. Caseins and casein hydrolysates. 2. Antioxidative properties and relevance to lipoxygenase inhibition. J. Agr. Food Chem. 2001, 49, 295-302. [CrossRef] [PubMed]

66. Miguel, M.; Gómez-Ruiz, J.A.; Recio, I.; Aleixandre, A. Changes in arterial blood pressure after single oral administration of milk-casein-derived peptides in spontaneously hypertensive rats. Mol. Nutr. Food Res. 2010, 54, 1422-1427. [CrossRef] [PubMed]

67. Sánchez-Rivera, L.; Ferreira Santos, P.; Miralles, B.; Carrón, R.; Montero, M.J.; Recio, I. Peptide fragments from $\beta$-casein $\mathrm{f}(134-138)$, HLPLP, generated by the action of rat blood plasma peptidases show potent antihypertensive activity. Food Res. Int. 2016, 88, 348-353. [CrossRef]

68. Abubakar, A.; Saito, T.; Kitazawa, H.; Kawai, Y.; Itoh, T. Structural analysis of new antihypertensive peptides derived from cheese whey protein by proteinase K digestion. J. Dairy Sci. 1998, 81, 3131-3138. [CrossRef]

69. Quirós, A.; Hernández-Ledesma, B.; Ramos, M.; Amigo, L.; Recio, I. Angiotensin-converting enzyme inhibitory activity of peptides derived from caprine kefir. J. Dairy Sci. 2005, 88, 3480-3487.

70. Dallas, D.C.; Citerne, F.; Tian, T.; Silva, V.L.; Kalanetra, K.M.; Frese, S.A.; Robinson, R.C.; Mills, D.A.; Barile, D. Peptidomic analysis reveals proteolytic activity of kefir microorganisms on bovine milk proteins. Food Chem. 2016, 15, 273-284. [CrossRef]

71. Wakai, T.; Yamamoto, N. Antihypertensive Peptides Specific to Lactobacillus helveticus Fermented Milk. In Biotechnology-Molecular Studies and Novel Applications for Improved Quality of Human Life; Sammour, R., Ed.; InTech: Rijeka, Croatian, 2012; ISBN 978-953-51-0151-2.

72. Saito, T.; Nakamura, T.; Kitazawa, H.; Kawai, Y.; Itoh, T. Isolation and structural analysis of antihypertensive peptides that exist naturally in Gouda cheese. J. Dairy Sci. 2000, 83, 1434-1440. [CrossRef] 
73. Amorim, F.G.; Coitinho, L.B.; Dias, A.T.; Friques, A.G.F.; Monteiro, B.L.; Rezende, L.C.D.; Pereira, T.M.C.; Campagnaro, B.P.; De Pauw, E.; Vasquez, E.C.; et al. Identification of new bioactive peptides from Kefir milk through proteopeptidomics: Bioprospection of antihypertensive molecules. Food Chem. 2019, 1, 109-119. [CrossRef]

74. Aluko, R.E. Anti-hypertensive peptides from food proteins. Annu. Rev. Food Sci. Technol. 2015, 6, $235-262$. [CrossRef]

75. Li, S.; Bu, T.; Zheng, J.; Liu, L.; He, G.; Wu, J. Preparation, bioavailability, and mechanism of emerging activities of Ile-Pro-Pro and Val-Pro-Pro. Compr. Rev. Food Sci. Food Saf. 2019, 18, 1097-1110. [CrossRef]

76. Beltrán-Barrientos, L.M.; Hernández-Mendoza, A.; Torres-Llanez, M.J.; González-Córdova, A.F.; Vallejo-Córdoba, B. Fermented milk as anti-hypertensive functional food. J. Dairy Sci. 2016, 99, 4099-4110. [CrossRef] [PubMed]

77. Nakamura, Y.; Yamamoto, N.; Sakai, K.; Okubo, A.; Yamazaki, S.; Takano, T. Purification and characterization of angiotensin I-converting enzyme inhibitors from sour milk. J. Dairy. Sci. 1995, 78, 777-783. [CrossRef]

78. Hebert, E.M.; Mamone, G.; Picariello, G.; Raya, R.R.; Savoy, G.; Ferranti, P.; Addeo, F. Characterization of the pattern of alpha(s1)- and beta-casein breakdown and release of a bioactive peptide by a cell envelope proteinase from Lactobacillus delbrueckii subsp. lactis CRL 581. Appl. Environ. Microbiol. 2008, 74, 3682-3689. [CrossRef] [PubMed]

79. Solieri, L.; Rutella, G.S.; Tagliazucchi, D. Impact of non-starter lactobacilli on release of peptides with angiotensin-converting enzyme inhibitory and antioxidant activities during bovine milk fermentation. Food Microbiol. 2015, 51, 108-116. [CrossRef]

80. Rutella, G.S.; Tagliazucchi, D.; Solieri, L. Survival and bioactivities of selected probiotic lactobacilli in yogurt fermentation and cold storage: New insights for developing a bi-functional dairy food. Food Microbiol. 2016, 60, 54-61. [CrossRef]

81. Bütikofer, U.; Meyer, J.; Sieber, R.; Wechsler, D. Quantification of the angiotensin-converting enzyme inhibiting tripeptides Val-Pro-Pro and Ile-Pro-Pro in hard, semi-hard and soft cheeses. Int. Dairy J. 2007, 17, 968-975. [CrossRef]

82. Bütikofer, U.; Meyer, J.; Sieber, R.; Walther, B.; Wechsler, D. Occurrence of the angiotensin-converting enzyme-inhibiting tripeptides Val-Pro-Pro and Ile-Pro-Pro in different cheese varieties of Swiss origin. J. Dairy Sci. 2008, 91, 29-38. [CrossRef]

83. Tagliazucchi, D.; Shamsia, S.; Conte, A. Release of angiotensin converting enzyme-inhibitory peptides during in vitro gastro-intestinal digestion of camel milk. Int. Dairy J. 2016, 56, 119-128. [CrossRef]

84. Tagliazucchi, D.; Shamsia, S.; Helal, A.; Conte, A. Angiotensin-converting enzyme inhibitory peptides from goats' milk released by in vitro gastro-intestinal digestion. Int. Dairy J. 2017, 71, 6-16. [CrossRef]

85. Tagliazucchi, D.; Martini, S.; Shamsia, S.; Helal, A.; Conte, A. Biological activities and peptidomic profile of in vitro-digested cow, camel, goat and sheep milk. Int. Dairy J. 2018, 81, 19-27. [CrossRef]

86. Rutella, S.G.; Solieri, L.; Martini, S.; Tagliazucchi, D. Release of the antihypertensive tripeptides Valine-Proline-Proline and Isoleucine-Proline-Proline from bovine milk caseins during in vitro gastrointestinal digestion. J. Agric. Food Chem. 2016, 64, 8509-8516. [CrossRef] [PubMed]

87. Xu, J.Y.; Qin, L.Q.; Wang, P.Y.; Li, W.; Chang, C. Effect of milk tripeptides on blood pressure: A meta-analysis of randomized controlled trials. Nutrition 2008, 24, 933-940. [CrossRef] [PubMed]

88. Miralles, B.; Amigo, L.; Recio, I. Critical review and perspectives on food-derived antihypertensive peptides. J. Agric. Food Chem. 2018, 66, 9384-9390. [CrossRef] [PubMed]

89. Quirós, A.; Dávalos, A.; Lasunción, M.A.; Ramos, M.; Recio, I. Bioavailability of the antihypertensive peptide LHLPLP: Transepithelial flux of HLPLP. Int. Dairy J. 2008, 18, 279-286. [CrossRef]

90. Kaiser, S.; Martin, M.; Lunow, D.; Rudolph, S.; Mertten, S.; Möckel, U.; Deußen, A.; Henle, T. Tryptophan-containing dipeptides are bioavailable and inhibit plasma human angiotensin-converting enzyme in vivo. Int. Dairy J. 2016, 52, 107-114. [CrossRef]

91. Korhonen, H.; Pihlanto, A. Technological options for the production of health-promoting proteins and peptides derived from milk and colostrum. Curr. Pharm. Des. 2007, 13, 829-843. [CrossRef]

92. Halliwell, B. Role of free radicals in the neurodegenerative diseases: Therapeutic implications for antioxidant treatment. Drugs Aging 2001, 18, 479-484. [CrossRef]

93. Liu, Q.; Raina, A.; Smith, M.; Sayre, L.; Perry, G. Hydroxynonenal, toxic carbonyls, and Alzheimer disease. Mol. Asp. Med. 2003, 24, 305-313. [CrossRef] 
94. Abuja, P.; Albertini, R. Methods for monitoring oxidative stress, lipid peroxidation and oxidation resistance of lipoproteins. Clin. Chim. Acta 2001, 306, 1-17. [CrossRef]

95. Halliwell, B. Lipid peroxidation, antioxidants and cardiovascular disease: How should we move forward? Cardiov. Res. 2000, 47, 410-418. [CrossRef]

96. Halliwell, B.; Whiteman, M. Measuring reactive species and oxidative damage in vivo and in cell culture: How should you do it and what do the results mean? Br. J. Pharm. 2004, 142, 231-255. [CrossRef] [PubMed]

97. Hoelzl, C.; Bichler, J.; Ferk, F.; Simic, T.; Nersesyan, A.; Elbling, L.; Ehrlich, V.; Chakraborty, A.; Knasmüller, S. Methods for the detection of antioxidants which prevent age related diseases: A critical review with particular emphasis on human intervention studies. J. Phys. Pharm. 2005, 56, 49-64.

98. Collins, A. Antioxidant intervention as a route to cancer prevention. Eur. J. Cancer 2005, 41, $1923-1930$. [CrossRef] [PubMed]

99. Packard, R.R.S.; Libby, P. Inflammation in atherosclerosis: From vascular biology to biomarker discovery and risk prediction. Clin. Chem. 2008, 54, 24-38. [CrossRef] [PubMed]

100. Libby, P. Inflammation in atherosclerosis. Nature 2002, 420, 868-874. [CrossRef] [PubMed]

101. Cichosz, G.; Czeczot, H.; Ambroziak, A.; Bielecka, M.M. Natural antioxidants in milk and dairy products. Int. J. Dairy Technol. 2017, 70, 165-178.

102. Lindmark-Månsson, H.; Åkesson, B. Antioxidative factors in milk. Br. J. Nutr. 2000, 84, 103-110. [CrossRef]

103. Park, Y.W. Overview of bioactive components in milk and dairy products. In Bioactive Components in Milk and Dairy Products; Park, Y.W., Ed.; Wiley-Blackwell Publishers: Ames, IA, USA; Oxford, UK, 2009; pp. 3-14.

104. Pihlanto, A. Lactic fermentation and bioactive peptides. In Lactic Acid Bacteria $R \mathcal{E} R$ for Food, Health and Livestock Purposes; IntechOpen: Marcelino, Kongo, 2013.

105. Hernández-Ledesma, B.; Amigo, L.; Ramos, M.; Recio, I. Application of high-performance liquid chromatography-tandem mass spectrometry to the identification of biologically active peptides produced by milk fermentation and simulated gastrointestinal digestion. J. Chromatogr. 2004, 1049, 107-114. [CrossRef]

106. Jin, Y.; Yub, Y.; Qi, Y.; Wang, F.; Yan, J.; Zou, H. Peptide profiling and the bioactivity character of yogurt in the simulated gastrointestinal digestion. J. Prot. 2016, 141, 24-46. [CrossRef]

107. Korhonen, H. Milk-derived bioactive peptides: From science to applications. J. Fun. Foods 2009, 1, $177-187$. [CrossRef]

108. Parrella, A.; Caterino, E.; Cangiano, M.; Criscuolo, E.; Russo, E.; Lavorgna, M.; Isidori, M. Antioxidant properties of different milk fermented with lactic acid bacteria and yeast. Int. J. Food Sci. Tech. 2012, 47, 2493-2502. [CrossRef]

109. Pattom, S.; Hongsprabhas, P. Effect of coagulants on antioxidant capacity of milk protein curds and their tryptic hydrolysates. J. Food Biochem. 2013, 37, 203-211.

110. Abadia-Garcia, L.; Cardador, A.; del Campo, M.S.T.; Arvizu, S.M.; Castano-Tostado, E.; Regalado-Gonzalez, C. Influence of probiotic strains added to cottage cheese on generation of potentially antioxidant peptides, antilisterial activity, and survival of probiotic microorganisms in simulated gastrointestinal conditions. Int. Dairy J. 2013, 33, 191-197. [CrossRef]

111. Kumar, S.; Teotia, U.V.S.; Sanghi, A. Antioxidative property of cow milk caseinates hydrolyzed with different proteases. Int. J. Pharm. Pharm. Sci. 2013, 5, 418-422.

112. Mushtaq, M.; Gani, A.; Masoodi, F.A.; Ahmad, M. Himalayan cheese (Kalari/Kradi)-Effect of different probiotic strains on oxidative stability, microbiological, sensory and nutraceutical properties during storage. Lwt-Food Sci. Technol. 2016, 67, 74-81. [CrossRef]

113. Pihlanto, A. Whey proteins and peptides: Emerging properties to promote health. Nutrafoods 2011, 10, $29-42$. [CrossRef]

114. Chang, O.K.; Seol, K.H.; Jeong, S.G.; Oh, M.H.; Park, B.Y.; Perrin, C.; Ham, J.S. Casein hydrolysis by Bifidobacterium longum KACC91563 and antioxidant activities of peptides derived therefrom. J. Dairy Sci. 2013, 96, 5544-5555. [CrossRef]

115. Power, O.; Jakeman, P.; FitzGerald, R.J. Antioxidative peptides: Enzymatic production, in vitro and in vivo antioxidant activity and potential applications of milk-derived antioxidative peptides. Amino Acids 2013, 44, 797-820. [CrossRef]

116. Ajibola, C.F.; Fashakin, J.B.; Fagbemi, T.N.; Aluko, R.E. Effect of Peptide Size on Antioxidant Properties of African Yam Bean Seed (Sphenostylis stenocarpa) Protein Hydrolysate Fractions. Int. J. Mol. Sci. 2011, 12, 6685-6702. [CrossRef] 
117. Pihlanto, A. Antioxidative peptides derived from milk proteins. Int. Dairy J. 2006, 16, 1306-1314. [CrossRef]

118. Tagliazucchi, D.; Helal, A.; Verzelloni, E.; Conte, A. Bovine milk antioxidant properties: Effect of in vitro digestion and identification of antioxidant compounds. Dairy Sci. Technol. 2016, 96, 657-676. [CrossRef]

119. Hernandez-Ledesma, B.; Miralles, B.; Amigo, L.; Ramos, M.; Recio, I. Identification of antioxidant and ACE-inhibitory peptides in fermented milk. J. Sci. Food Agric. 2005, 85, 1041-1048. [CrossRef]

120. Yamaguchi, N.; Yokoo, Y.; Fujimaki, M. Studies on antioxidative activities of amino compounds on fats and oils. Part II. Antioxidative activities of dipeptides and their synergistic effects on tocopherol. Nippon Shokuhin Kogyo Gakkaishi 1975, 22, 425-430. [CrossRef]

121. Chen, H.M.; Muramoto, K.; Yamauchi, F.; Fujimoto, K.; Nokihara, K. Antioxidative properties of histidine-containing peptides designed from peptide fragments found in the digests of a soybean protein. $J$. Agric. Food Chem. 1998, 46, 49-53. [CrossRef] [PubMed]

122. Kitts, D.D.; Weiler, K. Bioactive proteins and peptides from food sources. Applications of bioprocesses used in isolation and recovery. Curr. Pharm. Des. 2003, 9, 1309-1323. [CrossRef]

123. Xiong, Y.L. Antioxidant peptides. In Bioactive Proteins and Peptides as Functional Foods and Neutraceuticals; Mine, Y., Jiang, B., Li-Chan, E., Eds.; Wiley-Blackwell: Ames, IA, USA, 2010; pp. 29-39.

124. Eisele, T.; Stressler, T.; Kranz, B.; Fischer, L. Bioactive peptides generated in an enzyme membrane reactor using Bacillus lentus alkaline peptidase. Eur. Food Res. Tech. 2013, 236, 483-490. [CrossRef]

125. Gupta, A.; Mann, B.; Kumar, R.; Sangwan, R.B. Identification of antioxidant peptides in cheddar cheese made with adjunct culture Lactobacillus casei ssp. casei 300. Milchwissenschaft 2010, 65, 396-399.

126. Rival, S.G.; Fornaroli, S.; Boeriu, C.G.; Wichers, H.J. Caseins and casein hydrolysates. 1. Lipoxygenase inhibitory properties. J. Agric. Food Chem. 2001, 49, 287-294. [CrossRef]

127. Farvin, K.H.S.; Baron, C.P.; Nielsen, N.S.; Otte, J.; Jacobsen, C. Antioxidant activity of yoghurt peptides: Part 2-characterisation of peptide fractions. Food Chem. 2010, 123, 1090-1097. [CrossRef]

128. Hernández-Ledesma, B.; Amigo, L.; Ramos, M.; Recio, I. Angiotensin converting enzyme inhibitory activity in commercial fermented products. Formation of peptides under simulated gastrointestinal digestion. $J$. Agric. Food Chem. 2004, 52, 1504-1510. [CrossRef] [PubMed]

129. Taha, S.; El Abd, M.; De Gobba, C.; Abdel-Hamid, M.; Khalil, E.; Hassan, D. Antioxidant and antibacterial activities of bioactive peptides in buffalo's yoghurt fermented with different starter cultures. Food. Sci. Biotechnol. 2017, 26, 1325-1332. [CrossRef] [PubMed]

130. Pisanu, S.; Pagnozzi, D.; Pes, M.; Pirisi, A.; Roggio, T.; Uzzau, S.; Addis, M.F. Differences in the peptide profile of raw and pasteurised ovine milk cheese and implications for its bioactive potential. Int. Dairy J. 2015, 42, 26-33. [CrossRef]

131. Korhonen, H.; Pihlanto, A. Food-derived bioactive peptides-opportunities for designing future foods. Curr. Pharm. Des. 2003, 9, 1297-1308. [CrossRef]

132. López-Expósito, I.; Quiros, A.; Amigo, L.; Recio, I. Casein hydrolysates as a source of antimicrobial, antioxidant and antihypertensive peptides. Lait 2007, 87, 241-249. [CrossRef]

133. Kohmura, M.; Nio, N.; Ariyoshi, Y. Inhibition of angiotensin-converting enzyme by synthetic peptide fragments of various beta-caseins. Agric. Biol. Chem. 1990, 54, 1101-1102. [CrossRef]

134. De Gobba, C.; Tompa, G.; Otte, J. Bioactive peptides from caseins released by cold active proteolytic enzymes from Arsukibacterium ikkense. Food Chem. 2014, 165, 205-215. [CrossRef]

135. Clare, D.A.; Catignani, G.L.; Swaisgood, H.E. Biodefense properties of milk: The role of antimicrobial proteins and peptides. Curr. Pharm. Des. 2003, 9, 1239-1255. [CrossRef]

136. FitzGerald, R.J.; Meisel, H. Milk protein hydrolysates and bioactive peptides. In Advanced Dairy Chemistry-1 Proteins; Fox, P.F., Mc Sweeney, P.L.H., Eds.; Springer: Boston, MA, USA, 2003; pp. 675-698.

137. Li, G.; Le, G.; Shi, Y.; Shrestha, S. Angiotensin I-converting enzyme inhibitory peptides derived from food proteins and their physiological and pharmacological effects. Nutr. Res. 2004, 24, 469-486. [CrossRef]

138. López-Expósito, I.; Recio, I. Antibacterial activity of peptides and folding variants from milk proteins. Int. Dairy J. 2006, 16, 1294-1305. [CrossRef]

139. López-Expósito, I.; Amigo, L.; Recio, I. Identification of the initial binding sites of $\alpha_{\mathrm{s} 2}$-casein $\mathrm{f}(183-207)$ and effect on bacterial membranes and cell morphology. Biochim. Biophys. Acta Biomembr. 2008, 1778, 2444-2449. [CrossRef]

140. Settanni, L.; Moschetti, G. Non-starter lactic acid bacteria used to improve cheese quality and provide health benefits. Food Microbiol. 2010, 27, 691-697. [CrossRef] 
141. Fontenele, M.A.; Bastos, M.S.R.; Dos Santos, K.M.O.; Bemquerer, M.P.; do Egito, A.S. Peptide profile of Coalho cheese: A contribution for Protected Designation of Origin (PDO). Food Chem. 2017, 15, 382-390. [CrossRef] [PubMed]

142. Lahov, E.; Regelson, W. Antibacterial and inmunostimulating casein-derived substances from milk: Casecidin, isracidin peptides. Fed. Chem. Toxic. 1996, 34, 131-145. [CrossRef]

143. López-Expósito, I.; Gómez-Ruiz, J.A.; Amigo, L.; Recio, I. Identification of antibacterial peptides from ovine as2-casein. Int. Dairy J. 2006, 16, 1072-1080. [CrossRef]

144. López-Expósito, I.; Minervini, F.; Amigo, L.; Recio, I. Identification of antibacterial peptides from bovine kappa-casein. J. Food Prot. 2006, 69, 2992-2997. [CrossRef]

145. Barbé, F.; Le Feunteun, S.; Rémond, D.; Ménard, O.; Jardin, J.; Henry, G.; Laroche, B.; Dupont, D. Tracking the in vivo release of bioactive peptides in the gut during digestion: Mass spectrometry peptidomic characterization of effluents collected in the gut of dairy matrices fed mini-pigs. Food Res. Int. 2014, 63, 147-156.

146. Yvon, M.; Pelissier, J.P. Characterization and kinetics of evacuation of peptides resulting from casein hydrolysis in the stomach of the calf. J. Agric. Food Chem. 1987, 35, 148-156. [CrossRef]

147. Boutrou, R.; Gaudichon, C.; Dupont, D.; Jardin, J.; Airinei, G.; Marsset-Baglieri, A.; Benamouzig, R.; Tomé, D.; Leonil, J. Sequential release of milk protein-derived bioactive peptides in the jejunum in healthy humans. Am. J. Clin. Nutr. 2013, 97, 1314-1323. [CrossRef]

148. World Health Organization, Diabetes Mellitus Fact Sheet. 2018. Available online: http://www.who.int/newsroom/fact-sheets/detail/diabetes (accessed on 1 September 2019).

149. Taylor, S.I. Deconstructing type 2 diabetes. Cell 1999, 97, 9-12. [CrossRef]

150. Nauck, M. Incretin therapies: Highlighting common features and differences in the modes of action of glucagon-like peptide-1 receptor agonists and dipeptidyl peptidase-4 inhibitors. Diabetes Obes. Metab. 2016, 18, 203-216. [CrossRef] [PubMed]

151. Rasmussen, H.B.; Branner, S.; Wiberg, F.C.; Wagtmann, N. Crystal structure of human dipeptidyl peptidase IV/CD26 in complex with a substrate analog. Nat. Struct. Biol. 2003, 10, 19-25. [CrossRef] [PubMed]

152. Mentlein, R. Dipeptidyl-peptidase IV (CD26)-Role in the inactivation of regulatory peptides. Regul. Pept. 1999, 85, 9-24. [CrossRef]

153. Langley, A.K.; Suffoletta, T.J.; Jennings, H.R. Dipeptidyl peptidase IV inhibitors and the incretin system in type 2 diabetes mellitus. Pharmacotherapy 2007, 27, 1163-1180. [CrossRef]

154. Vilsbøll, T.; Krarup, T.; Madsbad, S.; Holst, J.J. No reactive hypoglycaemia in Type 2 diabetic patients after subcutaneous administration of GLP-1 and intravenous glucose. Diabet. Med. 2001, 18, 144-149. [CrossRef]

155. Nongonierma, A.B.; FitzGerald, R.J. An in silico model to predict the potential of dietary proteins as sources of dipeptidyl peptidase IV (DPP-IV) inhibitory peptides. Food Chem. 2014, 165, 489-498. [CrossRef]

156. Lacroix, I.M.E.; Li-Chan, E.C.Y. Evaluation of the potential of dietary Proteins as precursors of dipeptidyl peptidase (DPP)-IV inhibitors by an in silico approach. J. Funct. Foods 2012, 4, 403-422. [CrossRef]

157. Uenishi, H.; Kabuki, T.; Seto, Y.; Serizawa, A.; Nakajima, H. Isolation and identification of casein-derived dipeptidyl-peptidase 4 (DPP-4)-inhibitory peptide LPQNIPPL from gouda-type cheese and its effect on plasma glucose in rats. Int. Dairy J. 2012, 22, 24-30. [CrossRef]

158. Li, C.; Kwok, L.-Y.; Mi, Z.; Bala, J.; Xue, J.; Yang, J. Characterization of the angiotensin-converting enzyme inhibitory activity of fermented milks produced with Lactobacillus casei. J. Dairy Sci. 2017, 100, 9495-9507. [CrossRef]

159. Jakubowicz, D.; Froy, O.; Ahren, B.; Boaz, M.; Landau, Z.; Bar-Dayan, Y.; Ganz, T.; Barnea, M.; Wainstein, J. Incretin, insulinotropic and glucose-lowering effects of whey protein pre-load in type 2 diabetes: A randomized clinical trial. Diabetologia 2014, 57, 1807-1811. [CrossRef]

160. Nongonierma, A.B.; FitzGerald, R.J. The scientific evidence for the role of milk protein-derived bioactive peptides in humans: A review. J. Funct. Foods 2015, 640, 640-656. [CrossRef]

161. Montel, M.C.; Buchin, S.; Mallet, A.; Delbés-Paus, C.; Vuitton, D.A.; Desmasures, N.; Berthier, F. Traditional cheeses: Rich and diverse microbiota with associated benefits. Int. J. Food Microbiol. 2014, 177, 136-154. [CrossRef] [PubMed]

162. EFSA-European Food Safety Authority. Update of the list of QPS-recommended biological agents intentionally added to food or feed as notified to EFSA 4: Suitability of taxonomic units notified to EFSA until March 2016. EFSA J. 2016, 14, 4522. 
163. Carminati, D.; Giraffa, G.; Zago, M.; Marcó, M.B.; Guglielmotti, D.; Binetti, A.; Reinheimer, J. Lactic acid bacteria for dairy fermentations. In Biotechnology of Lactic Acid Bacteria: Novel Applications, 2nd ed.; Mozzi, F., Raya, R.R., Vignolo, G.M., Eds.; John Wiley \& Sons, Ltd.: New York, NY, USA, 2015; pp. 191-208.

164. Cogan, T.M.; Beresford, T.P.; Steele, J.; Broadbent, J.; Shah, N.P.; Ustunol, Z. Invited review: Advances in starter cultures and cultured foods. J. Dairy Sci. 2007, 90, 4005-4021. [CrossRef] [PubMed]

165. Blaya, J.; Barzideh, Z.; LaPointe, G. Interaction of starter cultures and nonstarter lactic acid bacteria in the cheese environment. J. Dairy Sci. 2018, 101, 1-19. [CrossRef]

166. Walsh, A.M.; Crispie, F.; Kilcawley, K.; O'Sullivan, O.; O'Sullivan, M.G.; Claesson, M.J.; Cotter, P.D. Microbial succession and flavour production in the fermented dairy beverage kefir. mSystems 2016, 1, e00052-16. [CrossRef]

167. Macori, G.; Cotter, P.D. Novel insights into the microbiology of fermented dairy foods. Curr. Opin. Biotechnol. 2018, 49, 172-178. [CrossRef]

168. Solieri, L.; Dakal, T.C.; Giudici, P. Next-generation sequencing and its potential impact on food microbial genomics. Ann. Microbiol. 2013, 63, 21-37. [CrossRef]

169. De Filippis, F.; Parente, E.; Ercolini, D. Metagenomics insights into food fermentations. Microb. Biotechnol. 2017, 10, 91-102. [CrossRef]

170. Yeluri Jonnala, B.R.; McSweeney, P.L.H.; Sheehan, J.J.; Cotter, P.D. Sequencing of the cheese microbiome and its relevance to industry. Front Microbiol. 2018, 9, 1020. [CrossRef]

171. Gobbetti, M.; Neviani, E.; Calasso, M.; De Angelis, M.; Fox, F.P.; Di Cagno, R. Drivers that establish and assembly the lactic acid bacteria biota in cheeses. Trends Food Sci. Technol. 2018, 78, 244-254. [CrossRef]

172. Makarova, K.; Slesarev, A.; Wolf, Y.; Sorokin, A.; Mirkin, B.; Koonin, E.; Pavlov, A.; Pavlova, N.; Karamychev, V.; Polouchine, N.; et al. Comparative genomics of the lactic acid bacteria. Proc. Natl. Acad. Sci. USA 2006, 103, 15611-15616. [CrossRef] [PubMed]

173. Kok, C.R.; Hutkins, R. Yogurt and other fermented foods as sources of health-promoting bacteria. Nutr. Rev. 2018, 76, 4-15. [CrossRef] [PubMed]

174. Abushelaibi, A.; Al-Mahadin, S.; El-Tarabily, K.; Shah, N.P.; Ayyash, M. Characterization of potential probiotic lactic acid bacteria isolated from camel milk. Lebensm. Wiss. Technol. 2017, 79, 316-325. [CrossRef]

175. Makete, G.; Aiyegoro, O.A.; Thantsha, M.S. Isolation, identification and screening of potential probiotic bacteria in milk from South African Saanen goats. Probiotics Antimicrob. Proteins 2017, 9, 246-254. [CrossRef]

176. Soleymanzadeh, N.; Mirdamadi, S.; Kianirad, M. Antioxidant activity of camel and bovine milk fermented by lactic acid bacteria isolated from traditional fermented camel milk (Chal). Dairy Sci. Technol. 2016, 96, 443-457. [CrossRef]

177. Solieri, L.; Bianchi, A.; Giudici, P. Inventory of non starter lactic acid bacteria from ripened Parmigiano Reggiano cheese as assessed by a culture dependent multiphasic approach. Syst. Appl. Microbiol. 2012, 35, 270-277. [CrossRef]

178. Pino, A.; Russo, N.; Van Hoorde, K.; De Angelis, M.; Sferrazzo, G.; Randazzo, C.L.; Caggia, C. Piacentinu Ennese PDO Cheese as reservoir of promising probiotic bacteria. Microorganisms 2019, 7, 254. [CrossRef]

179. Pino, A.; Van Hoorde, K.; Pitino, I.; Russo, N.; Carpino, S.; Caggia, C.; Randazzo, C.L. Survival of potential probiotic lactobacilli used as adjunct cultures on Pecorino Siciliano cheese ripening and passage through the gastrointestinal tract of healthy volunteers. Int. J. Food Microbiol. 2017, 252, 42-52. [CrossRef]

180. Zoumpopoulou, G.; Tzouvanou, A.; Mavrogonatou, E.; Alexandraki, V.; Georgalaki, M.; Anastasiou, R.; Papadelli, M.; Manolopoulou, E.; Kazou, M.; Kletsas, D.; et al. Probiotic features of lactic acid bacteria isolated from a diverse pool of traditional Greek dairy products regarding specific strain-host interactions. Prob. Antimicrob. Proteins. 2018, 10, 313-322. [CrossRef]

181. Ołdak, A.; Zielińska, D.; Łepecka, A.; Długosz, E.; Kołożyn-Krajewska, D. Lactobacillus plantarum strains isolated from Polish regional cheeses exhibit anti-staphylococcal activity and selected probiotic properties. Probiotics Antimicrob. Proteins. 2019. [Epub ahead of print]. [CrossRef] [PubMed]

182. Moyano, S.; Gonçalves dos Santos, M.T.; Galván, A.I.; Merchán, A.; González, E.; de Guía Córdoba, M.; Benito, M.J. Screening of autochthonous lactic acid bacteria strains from artisanal soft cheese: Probiotic characteristics and prebiotic metabolism. LWT-Food Sci. Technol. 2019, 114, 108388. [CrossRef]

183. Reid, G.; Gadir, A.A.; Dhir, R. Probiotics: Reiterating what they are and what they are not. Front. Microbiol. 2019. [CrossRef] [PubMed] 
184. Sanders, M.E.; Benson, A.; Lebeer, S.; Merenstein, D.J.; Klaenhammer, T.R. Shared mechanisms among probiotic taxa: Implications for general probiotic claims. Curr. Opin. Biotechnol. 2018, 49, 207-216. [CrossRef]

185. Linares, D.M.; Gómez, C.; Renes, E.; Fresno, J.M.; Tornadijo, M.E.; Ross, R.P.; Stanton, C. Lactic acid bacteria and bifidobacteria with potential to design natural biofunctional health-promoting dairy foods. Front. Microbiol. 2018, 8, 846. [CrossRef]

186. Quan, S.; Tsuda, H.; Miyamoto, T. Angiotensin I-converting enzyme inhibitory peptides in skim milk fermented with Lactobacillus helveticus 130B4 from camel milk in inner Mongolia, China. J. Sci. Food Agric. 2018, 88, 2688-2692. [CrossRef]

187. Gonzalez-Gonzalez, C.R.; Machado, J.; Correia, S.; McCartney, A.L.; Elmore, J.S.; Jauregi, P. Highly proteolytic bacteria from semi-ripened Chiapas cheese elicit angiotensin-I converting enzyme inhibition and antioxidant activity. LWT-Food Sci. Technol. 2019, 111, 449-456. [CrossRef]

188. Yamamoto, N.; Kawakami, N.; Ishida, Y.; Yada, H. Lactobacillus helveticus Bacterium Having High Capability of Producing Tripeptides, Fermented Milk Product, and Process for Preparing the Same. U.S. patent 09/508840, 18 March 2003.

189. Chen, Y.; Liu, W.; Xue, J.; Yang, J.; Chen, X.; Shao, Y.; Kwok, L.Y.; Bilige, M.; Mang, L.; Zhang, H. Angiotensin-converting enzyme inhibitory activity of Lactobacillus helveticus strains from traditional fermented dairy foods and antihypertensive effect of fermented milk of strain H9. J. Dairy Sci. 2014, 97, 6680-6692. [CrossRef]

190. Skrzypczak, K.; Gustaw, W.; Szwajgier, D.; Fornal, E.; Waśko, A. k-Casein as a source of short-chain bioactive peptides generated by Lactobacillus helveticus. J. Food Sci. Technol. 2017, 54, 3679-3688. [CrossRef]

191. Elfahri, K.; Donkor, O.; Vasiljevic, T. Potential of novel Lactobacillus helveticus strains and their cell wall bound proteases to release physiologically active peptides from milk proteins. Int. Dairy J. 2014, 38, 37-46. [CrossRef]

192. Jensen, M.P.; Vogensen, F.K.; Ardö, Y. Variation in caseinolytic properties of six cheese related Lactobacillus helveticus strains. Int. Dairy J. 2009, 19, 661-668. [CrossRef]

193. Hati, S.; Sakure, A.; Mandal, S. Impact of proteolytic Lactobacillus helveticus MTCC5463 on production of bioactive peptides derived from honey based fermented milk international. J. Pep. Res. Ther. 2017, 23, 297-303. [CrossRef]

194. Atanasova, J.; Moncheva, P.; Ivanova, I. Proteolytic and antimicrobial activity of lactic acid bacteria grown in goat milk. Biotechnol. Equip. 2014, 28, 1073-1078. [CrossRef] [PubMed]

195. Wang, H.; Cui, L.; Chen, W.; Zhang, H. An application in Gouda cheese manufacture for a strain of Lactobacillus helveticus ND01. Int. J. Dairy Technol. 2011, 64, 386-393. [CrossRef]

196. Minervini, F.; Algaron, F.; Rizzello, C.G.; Fox, P.F.; Monnet, V.; Gobbetti, M. Angiotensin I-convertingenzyme-inhibitory and antibacterial peptides from Lactobacillus helveticus PR4 proteinase-hydrolyzed caseins of milk from six species. Appl. Environ. Microbiol. 2003, 69, 5297-5305. [CrossRef]

197. Beganović, J.; Kos, B.; Pavunc, A.L.; Uroić, K.; Džidara, P.; Šušković, J. Proteolytic activity of probiotic strain Lactobacillus helveticus M92. Anaerobe 2013, 20, 58-64.

198. Wang, J.H.K.; Dong, C.; Chen, Y.F.; Cui, L.M.; Zhang, H. A new probiotic Cheddar cheese with high ACE-inhibitory activity and $\gamma$-aminobutyric acid content produced with koumiss-derived Lactobacillus casei Zhang. Food Technol. Biotechnol. 2010, 48, 62-70.

199. Ahn, J.E.; Park, S.Y.; Atwal, A.; Gibbs, B.F.; Lee, B.H. Angiotensin i-converting enzyme (ACE) inhibitory peptides from whey fermented by Lactobacillus species. J. Food Biochem. 2009, 33, 587-602. [CrossRef]

200. Abdel-Hamid, M.; Romeih, A.; Gamba, R.R.; Nagai, E.; Suzuki, T.; Koyanagi, T.; Enomoto, T. The biological activity of fermented milk produced by Lactobacillus casei ATCC 393 during cold storage. Int. Dairy J. 2019, 91, 1-8. [CrossRef]

201. Sah, B.N.P.; Vasiljevic, T.; McKechnie, S.; Donkor, O.N. Effect of probiotics on antioxidant and antimutagenic activities of crude peptide extract from yogurt. Food Chem. 2014, 156, 264-270. [CrossRef]

202. Didelot, S.; Bordenave-Juchereau, S.; Rosenfeld, E.; Piot, J.M.; Sannier, F. Peptides released from acid goat whey by a yeast-lactobacillus association isolated from cheese microflora. J. Dairy Res. 2006, 73, 163-170. [CrossRef] [PubMed]

203. Solanki, D.; Hati, S. Considering the potential of Lactobacillus rhamnosus for producing Angiotensin I-Converting Enzyme (ACE) inhibitory peptides in fermented camel milk (Indian breed). Food Biosci. 2018, 23, 16-22. [CrossRef] 
204. Moslehishad, M.; Ehsani, M.R.; Salami, M.; Mirdamadi, S.; Ezzatpanah, A.; Naslaji, A.N.; Moosavi-Movahedi, A.A. The comparative assessment of ACE-inhibitory and antioxidant activities of peptide fractions obtained from fermented camel and bovine milk by Lactobacillus rhamnosus PTCC 1637. Int. Dairy J. 2013, 29, 82-87. [CrossRef]

205. Aguilar-Toalá, J.E.; Santiago-López, L.; Peres, C.M.; Peres, C.; Garcia, H.S.; Vallejo-Cordoba, B. Assessment of multifunctional activity of bioactive peptides derived from fermented milk by specific Lactobacillus plantarum strains. J. Dairy Sci. 2017, 100, 65-75. [CrossRef] [PubMed]

206. Ayyash, M.; Al-Dhaheri, A.S.; Al Mahadin, S.; Kizhakkayil, J.; Abushelaibi, A. In vitro investigation of anticancer, antihypertensive, antidiabetic, and antioxidant activities of camel milk fermented with camel milk probiotic: A comparative study with fermented bovine milk. J. Dairy Sci. 2018, 101, 900-911. [CrossRef]

207. Al-Dhaheri, A.S.; Al-Hemeiri, R.; Kizhakkayil, J.; Al-Nabulsi, A.; Abushelaibi, A.; Shah, N.P.; Ayyash, M. Health-promoting benefits of low-fat akawi cheese made by exopolysaccharide-producing probiotic Lactobacillus plantarum isolated from camel milk. J. Dairy Sci. 2017, 100, 7771-7779. [CrossRef]

208. Chen, L.; Zhang, Q.; Ji, Z.; Shu, G.; Chen, H. Production and fermentation characteristics of angiotensinconverting enzyme inhibitory peptides of goat milk fermented by a novel wild Lactobacillus plantarum 69. LWT-Food Sci. Technol. 2018, 91, 532-540. [CrossRef]

209. Vukotić, G.; Strahinić, I.; Begović, J.; Lukić, J.; Kojić, M.; Fira, D. Survey on proteolytic activity and diversity of proteinase genes in mesophilic lactobacilli. Microbiology 2016, 85, 33-41.

210. Gobbetti, M.; Ferranti, P.; Smacchi, E.; Goffredi, F.; Addeo, F. Production of Angiotensin-I-Convertingenzyme-inhibitory peptides in fermented milks started by Lactobacillus delbrueckii subsp. bulgaricus SS1 and Lactococcus lactis subsp. cremoris FT4. Appl. Environ. Microbiol. 2000, 66, 3898-3904. [CrossRef]

211. Georgalaki, M.; Zoumpopoulou, G.; Mavrogonatou, E.; Van Driessche, G.; Alexandraki, V.; Anastasiou, R. Evaluation of the antihypertensive angiotensin-converting enzyme inhibitory (ACE-I) activity and other probiotic properties of lactic acid bacteria isolated from traditional Greek dairy products. Int. Dairy J. 2017, 75, 10-21. [CrossRef]

212. Villegas, J.M.; Picariello, G.; Mamone, G.; Espeche Turbay, M.B.; Savoy de Giori, G.; Hebert, E.M. Milk-derived angiotensin-I-converting enzyme inhibitory peptides generated by Lactobacillus delbrueckii subsp. lactis CRL 581. Peptidomics 2014, 1, 22-29. [CrossRef]

213. Rodríguez-Figueroa, J.C.; González-Córdova, A.F.; Torres-Llanez, M.J.; Garciía, H.S.; Vallejo-Cordoba, B. Novel angiotensin I-converting enzyme inhibitory peptides produced in fermented milk by specific wild Lactococcus lactis strains. J. Dairy Sci. 2012, 95, 5536-5543. [CrossRef] [PubMed]

214. Rodríguez-Figueroa, J.C.; Reyes-Díaz, R.; González-Córdova, A.F.; Troncoso-Rojas, R.; Vargas-Arispuro, I.; Vallejo-Cordoba, B. Angiotensin-converting enzyme inhibitory activity of milk fermented by wild and industrial Lactococcus lactis strains. J. Dairy Sci. 2010, 93, 5032-5038. [CrossRef] [PubMed]

215. Picon, A.; Garde, S.; Ávila, M.; Nuñez, M. Proteolytic activities, peptide utilization and oligopeptide transport systems of wild Lactococcus lactis strains. Int. Dairy J. 2010, 20, 156-162. [CrossRef]

216. Soleymanzadeh, N.; Mirdamadi, S.; Mirzaei, M.; Kianirad, M. Novel $\beta$-casein derived antioxidant and ACE-inhibitory active peptide from camel milk fermented by Leuconostoc lactis PTCC1899: Identification and molecular docking. Int. Dairy J. 2019, 97, 201-208. [CrossRef]

217. Miclo, L.; Roux, E.; Genay, M.; Brusseaux, E.; Poirson, C.; Jameh, N.; Perrin, C.; Dary, A. Variability of hydrolysis of $\beta-, \alpha s 1-$, and $\alpha$ s2-caseins by 10 strains of Streptococcus thermophilus and resulting bioactive peptides. J. Agric. Food Chem. 2012, 60, 554-565. [CrossRef]

218. Balthazar, C.F.; Santillo, A.; Guimarães, G.T.; Capozzi, V.; Russo, P.; Caroprese, M.; Marino, R.; Esmerino, A.E.; Raices, R.S.L.; Silva, M.C.; et al. Novel milk-juice beverage with fermented sheep milk and strawberry $($ Fragaria $\times$ ananassa): Nutritional and functional characterization. J. Dairy Sci. 2019, in press. [CrossRef]

219. Ong, L.; Henriksson, A.; Shah, N.P. Proteolytic pattern and organic acid profiles of probiotic Cheddar cheese as influenced by probiotic strains of Lactobacillus acidophilus, Lb. paracasei, Lb. casei or Bifidobacterium sp. Int. Dairy J. 2007, 17, 67-78. [CrossRef]

220. Padghan, P.V.; Mann, B.; Sharma, R.; Bajaj, R.; Saini, P. Production of Angiotensin-I-Converting-EnzymeInhibitory Peptides in Fermented Milks (Lassi) Fermented by Lactobacillus acidophillus with Consideration of Incubation Period and Simmering Treatment. Int. J. Pept. Res Ther. 2016, 23, 69-79. [CrossRef]

221. Muguerza, B.; Ramos, M.; Sánchez, E.; Manso, M.A.; Miguel, M.; Aleixandre, A.; Delgado, M.A.; Recio, I. Antihypertensive activity of milks fermented by Enterococcus faecalis strains isolated from raw milk. Int. Dairy J. 2006, 16, 61-69. [CrossRef] 
222. Biscola, V.; Choiset, Y.; Rabesona, H.; Chobert, J.M.; Haertlé, T.; Franco, B.D.G.M. Brazilian artisanal ripened cheeses as sources of proteolytic lactic acid bacteria capable of reducing cow milk allergy. J. Appl. Microbiol. 2018, 125, 564-574. [CrossRef] [PubMed]

223. Ebner, J.; Arslan, A.A.; Fedorova, M.; Hoffmann, R.; Küçükçetin, A.; Pischetsrieder, M. Peptide profiling of bovine kefir reveals 236 unique peptides released from caseins during its production by starter culture or kefir grains. J. Proteom. 2018, 117, 41-57. [CrossRef] [PubMed]

224. Leclerc, P.-L.; Gauthier, S.; Bachelard, H.; Santure, M.; Roy, D. Antihypertensive activity of casein-enriched milk fermented by Lactobacillus helveticus. Int. Dairy J. 2002, 12, 995-1004. [CrossRef]

225. Raveschot, C.; Cudennec, B.; Deracinois, B.; Frémont, M.; Vaeremans, M.; Dugersuren, J.; Demberel, S.; Drider, D.; Dhulster, P.; Coutte, F.; et al. Proteolytic activity of Lactobacillus strains isolated from Mongolian traditional dairy products: A multiparametric analysis. Food Chem. 2020, 304, 125415. [CrossRef] [PubMed]

226. Griffiths, M.W.; Tellez, A.M. Lactobacillus helveticus: The proteolytic system. Front Microbiol. 2013, 4, 30. [CrossRef]

227. O'Sullivan, O.; O'Callaghan, J.; Sangrador-Vegas, A. Comparative genomics of lactic acid bacteria reveals a niche-specific gene set. BMC Microbiol. 2009, 9, 50. [CrossRef]

228. Alcántara, C.; Bäuerl, C.; Revilla-Guarinos, A.; Pérez-Martínez, G.; Monedero, V.; Zúñiga, M. Peptide and amino acid metabolism is controlled by an OmpR-family response regulator in Lactobacillus casei. Mol. Microbiol. 2016, 100, 25-41. [CrossRef]

229. Kunji, E.R.S.; Mierau, I.; Hagting, A.; Poolman, B.; Konings, W.N. The proteolytic systems of lactic acid bacteria. Ant. Leeuw. Int. 1996, 70, 187-221. [CrossRef]

230. Sadat-Mekmene, L.; Jardin, J.; Corre, C.; Mollé, D.; Richoux, R.; Delage, M.M.; Lortal, S.; Gagnaire, V. Simultaneous presence of PrtH and PrtH2 proteinases in Lactobacillus helveticus strains improves breakdown of the pure $\alpha$ s1-casein. Appl. Environ. Microbiol. 2011, 77, 179-186. [CrossRef]

231. Liu, M.; Bayjanov, J.R.; Renckens, B.; Nauta, A.; Siezen, R.J. The proteolytic system of lactic acid bacteria revisited: A genomic comparison. BMC Genomics. 2010, 11, 36. [CrossRef]

232. Sun, Z.; Harris, H.M.; McCann, A.; Guo, C.; Argimon, S.; Zhang, W.; Yang, X.; Jeffery, I.B.; Cooney, J.C.; Kagawa, T.F.; et al. Expanding the biotechnology potential of lactobacilli through comparative genomics of 213 strains and associated genera. Nat. Commun. 2015, 6, 8322. [CrossRef] [PubMed]

233. Pederson, J.A.; Mileski, G.J.; Weimer, B.C.; Steele, J.L. Genetic characterization of a cell envelope-associated proteinase from Lactobacillus helveticus CNRZ32. J. Bacteriol. 1999, 181, 4592-4597. [PubMed]

234. Genay, M.; Sadat, L.; Gagnaire, V.; Lortal, S. prtH2 and not prtH is the ubiquitous cell-wall proteinase gene in Lactobacillus helveticus. Appl. Environ. Microbiol. 2009, 19, 89-95. [CrossRef] [PubMed]

235. Broadbent, J.R.; Hughes, J.E.; Welker, D.L.; Tompkins, T.A.; Steele, J.L. Complete genome sequence for Lactobacillus helveticus CNRZ 32, an industrial cheese starter and cheese flavour adjunct. Genome Announc. 2013, 1, e00590-13. [CrossRef]

236. Savijoki, K.; Ingmer, H.; Varmanen, P. Proteolytic systems of lactic acid bacteria. Appl. Microbiol. Biotechnol. 2006, 71, 394-406. [CrossRef]

237. Zhao, W.; Chen, Y.; Sun, Z.; Wang, J.; Zhou, Z.; Sun, T.; Wang, J.; Zhou, Z.; Sun, T.; Wang, L.; et al. Complete genome sequence of Lactobacillus helveticus H10. J. Bacteriol. 2011, 193, 2666-2667. [CrossRef]

238. Tynkkynen, S.; Buist, G.; Kunji, E.; Kok, J.; Poolman, B.; Venema, G.; Haandrikman, A. Genetic and biochemical characterization of the oligopeptide transport system of Lactococcus lactis. J. Bacteriol. 1993, 175, 7523-7532. [CrossRef]

239. Detmers, F.J.M.; Kunji, E.R.S.; Lanfermeijer, F.C.; Poolman, B.; Konings, W.N. Kinetics and specificity of peptide uptake by the oligopeptide transport system of Lactococcus lactis. Biochemistry 1998, 37, 16671-16679. [CrossRef]

240. Doeven, M.K.; Abele, R.; Tampé, R.; Poolman, B. The binding specificity of OppA determines the selectivity of the oligopeptide ATP-binding cassette transporter. J. Biol. Chem. 2004, 279, 32301-32307. [CrossRef]

241. Peltoniemi, K.; Vesanto, E.; Palva, A. Genetic characterization of an oligopeptide transport system from Lactobacillus delbrueckii subsp. Bulgaricus. Arch. Microbiol. 2002, 177, 457-467. [CrossRef]

242. Hagting, A.; Kunji, E.R.S.; Leenhouts, K.J.; Poolman, B.; Konings, W.N. The di- and tripeptide transport protein of Lactococcus lactis: A new type of bacterial transporter. J. Biol. Chem. 1994, 269, 11391-11399. [PubMed] 
243. Nakajima, H.; Hagting, A.; Kunji, E.R.; Poolman, B.; Konings, W.N. Cloning and functional expression in Escherichia coli of the gene encoding the di- and tripeptide transport protein of Lactobacillus helveticus. Appl. Environ. Microbiol. 1997, 63, 2213-2217.

244. Foucaud, C.; Kunji, E.R.S.; Hagting, A.; Richard, J.; Konings, W.N.; Desmazeaud, M.; Poolman, B. Specificity of peptide transport systems in Lactococcus lactis: Evidence for third system which transport hydrophobic diand tripeptides. J. Bacteriol. 1995, 177, 4652-4657. [CrossRef] [PubMed]

245. Sanz, Y.; Lanfermeijer, F.C.; Renault, P.; Bolotin, A.; Konings, W.N.; Poolman, B. Genetic and functional characterization of $d p p$ genes encoding a dipeptide transport system in Lactococcus lactis. Arch. Microbiol. 2001, 175, 334-343. [CrossRef] [PubMed]

246. Doeven, M.K.; Kok, J.; Poolman, B. Specificity and selectivity determinants of peptide transport in Lactococcus lactis and other microorganisms. Mol. Microbiol. 2005, 57, 640-649. [CrossRef]

247. Christensen, J.E.; Dudley, E.G.; Pederson, J.A.; Steele, J.L. Peptidases and amino acid catabolism in lactic acid bacteria. Antonie Van Leeuwenhoek 1999, 76, 217-246. [CrossRef] [PubMed]

248. Klein, J.R.; Schick, J.; Henrich, B.; Plapp, R. Lactobacillus delbrueckii subsp. lactis DSM7290 pepG gene encodes a novel cysteine aminopeptidase. Microbiology 1997, 143, 527-537. [CrossRef]

249. Fenster, H.M.; Parkin, K.M.; Steele, J.L. Characterization of a Thiol-Dependent Endopeptidase from Lactobacillus helveticus CNRZ32. J. Bacteriol. 1997, 179, 2529-2533. [CrossRef]

250. Shridar, V.M.; Hughes, J.E.; Welker, D.L.; Broadbent, J.R.; Steele, J.L. Identification of endopeptidase genes from the genomic sequence of Lactobacillus helveticus CNRZ32 and the role of these genes in hydrolysis of model bitter peptides. Appl. Environ. Microbiol. 2005, 71, 3025-3032. [CrossRef]

251. Monnet, V.; Nardi, M.; Chopin, A.; Chopin, M.C.; Gripon, J.C. Biochemical and genetic characterization of PepF, an oligopeptidase from Lactococcus lactis. J. Biol. Chem. 1994, 269, 32070-32076.

252. Pritchard, G.G.; Freebairn, A.D.; Coolbear, T. Purification and characterization of an endopeptidase from Lactococcus lactis subsp. cremoris SK11. Microbiology 1994, 140, 923-930. [CrossRef] [PubMed]

253. Chen, Y.S.; Christensen, J.E.; Broadbent, J.R.; Steele, J.L. Identification and characterization of Lactobacillus helveticus PepO2, an endopeptidase with post-proline specificity. Appl. Environ. Microbiol. 2003, 69, 1276-1282. [CrossRef] [PubMed]

254. Fernández de Palencia, P.; Peláez, C.; Martín-Hernández, C. Purification and characterization of an aminopeptidase (Pep C-like) from Lactobacillus casei subsp. casei IFPL 731 isolated from raw goat's milk cheese. Int. Dairy J. 1997, 7, 629-634.

255. Fernández de Palencia, P.; Peláez, C.; Martín-Hernández, C. Characterization of the aminopeptidase system from Lactobacillus casei subsp. casei IFPL 731. J. Agric. Food Chem. 1997, 45, 3778-3781.

256. Vesanto, E.; Vermanen, P.; Steele, J.L.; Palva, A. Characterization and expression of the Lactobacillus helveticus рерC gene encoding a general aminopeptidase. Eur. J. Biochem. 1994, 224, 991-997. [CrossRef] [PubMed]

257. Klein, J.R.; Klein, U.; Schad, M.; Plapp, R. Cloning, DNA sequence analysis and partial characterization of pepN, a lysyl aminopeptidase from Lactobacillus delbrueckii ssp. lactis DSM7290. Eur. J. Biochem. 1993, 217, 105-114. [CrossRef]

258. Bouchier, P.L.; FitzGerald, R.J.; O'Cuinn, G. Hydrolysis of $\alpha$ s1- and $\beta$-casein-derived peptides with a broad specificity aminopeptidase and proline specific aminopeptidases from Lactococcus lactis subsp. cremoris AM2. FEBS Lett. 1999, 445, 321-324. [CrossRef]

259. Mars, I.; Monnet, V. An aminopeptidase P from Lactococcus lactis with original specificity. Biochim. Biophys. Acta 1995, 1243, 209-215. [CrossRef]

260. El Abboudi, M.; El Soda, M.; Pandian, S.; Simard, R.E.; Olson, N.F. Purification of X-prolyl dipeptidyl aminopeptidase from Lactobacillus casei subspecies. Int. J. Food Microbiol. 1992, 15, 57-98. [CrossRef]

261. Stressler, T.; Eisele, T.; Kranz, B.; Fischer, L. PepX from Lactobacillus helveticus: Automated multi-step purification and determination of kinetic parameters with original tripeptide substrates. J. Mol. Catal. B-Enzym. 2017, 108, 103-110. [CrossRef]

262. Fernández-Espla, M.D.; Martín-Hernández, M.C. Purification and characterization of a dipeptidase from Lactobacillus casei ssp. casei IFPL 731 isolated from goat cheese made from raw milk. J. Dairy Sci. 1997, 80, 1497-1504. [CrossRef]

263. Savijoki, K.; Palva, A. Purification and molecular characterization of a tripeptidase (PepT) from Lactobacillus helveticus. Appl. Environ. Microbiol. 2000, 66, 794-800. [CrossRef] [PubMed] 
264. Varmanen, P.; Rantanen, T.; Palva, A.; Tynkkynen, S. Cloning and characterization of a prolinase gene (pepR) from Lactobacillus rhamnosus. Appl. Environ. Microbiol. 1998, 64, 1831-1836. [PubMed]

265. Varmanen, P.; Rantanen, T.; Palva, A. An operon from Lactobacillus helveticus composed of a proline iminopeptidase gene (pepI) and two genes coding for putative members of the ABC transporter family of proteins. Microbiology 1996, 142, 3459-3468. [CrossRef] [PubMed]

266. Fernández-Espla, M.D.; Martín-Hernández, M.C.; Fox, P.F. Purification and characterization of a prolidase from Lactobacillus casei subsp. casei IFPL 731. Appl. Environ. Microbiol. 1997, 63, 314-316.

267. Cai, H.; Thompson, R.; Budinich, M.; Broadbent, J.R.; Steele, J.L. Genome sequence and comparative genome analysis of Lactobacillus casei: Insights into their niche-associated evolution. Genome Biol. Evol. 2009, 1, 239-257. [CrossRef]

268. Pangallo, D.; Kraková, L.; Puškárová, A.; Šoltys, K.; Bučková, M.; Koreňová, J.; Budiš, J.; Kuchta, T. Transcription activity of lactic acid bacterial proteolysis-related genes during cheese maturation. Food Microbiol. 2019, 82, 416-425. [CrossRef]

269. Soeryapranata, E.; Powers, J.R.; Ünlü, G. Cloning and characterization of debittering peptidases, PepE, PepO, PepO2, PepO3, and PepN, of Lactobacillus helveticus WSU19. Int. Dairy J. 2007, 17, 1096-1106. [CrossRef]

270. Parra, L.; Fernández de Palencia, P.; Casal, V.; Requena, T.; Peláez, C. Hydrolysis of $\beta$-casein (193-209) fragment by whole cells and fractions of Lactobacillus casei and Lactococcus lactis. J. Food Sci. 1999, 64, 899-902. [CrossRef]

271. Ueno, K.; Mizuno, S.; Yamamoto, N. Purification and characterization of an endopeptidase that has an important role in the carboxyl terminal processing of antihypertensive peptides in Lactobacillus helveticus CM4. Lett. Appl. Microbiol. 2004, 39, 313-318. [CrossRef]

272. Cremonesi, P.; Chessa, S.; Castiglioni, B. Genome sequence and analysis of Lactobacillus helveticus. Front. Microbiol. 2013, 3, 435. [CrossRef] [PubMed]

273. Wakai, T.; Yamaguchi, N.; Hatanaka, M.; Nakamura, Y.; Yamamoto, N. Repressive processing of antihypertensive peptides, Val-Pro-Pro and Ile-Pro-Pro, in Lactobacillus helveticus fermented milk by added peptides. J. Biosci. Bioeng. 2012, 114, 133-137. [CrossRef] [PubMed]

274. Guédon, E.; Renault, P.; Ehrlich, S.D.; Delorme, C. Transcriptional pattern of genes coding for the proteolytic system of Lactococcus lactis and evidence for coordinated regulation of key enzymes by peptide supply. $J$. Bacteriol. 2001, 183, 3614-3622. [CrossRef] [PubMed]

275. Chambellon, E.; Yvon, M. CodY-Regulated Aminotransferases AraT and BcaT play a major role in the growth of Lactococcus lactis in milk by regulating the intracellular pool of amino acids. Appl. Environ. Microbiol. 2003, 69, 3061-3068. [CrossRef]

276. Wakai, T.; Yamamoto, N. A novel branched chain amino acids responsive transcriptional regulator, BCARR, negatively acts on the proteolytic system in Lactobacillus helveticus. PLoS ONE 2013, 8, e75976. [CrossRef]

277. Brown, L.; Villegas, J.M.; Elean, M.; Fadda, S.; Mozzi, F.; Saavedra, L.; Hebert, H.M. YebC, a putative transcriptional factor involved in the regulation of the proteolytic system of Lactobacillus. Sci. Rep. 2017, 7, 8579. [CrossRef]

(C) 2019 by the authors. Licensee MDPI, Basel, Switzerland. This article is an open access article distributed under the terms and conditions of the Creative Commons Attribution (CC BY) license (http://creativecommons.org/licenses/by/4.0/). 